Article

\title{
Acellular Pertussis Vaccine Inhibits Bordetella pertussis Clearance from the Nasal Mucosa of Mice
}

\author{
Jana Holubová ${ }^{1}$, Ondřej Staněk ${ }^{1}$, Ludmila Brázdilová ${ }^{1}$, Jiři Mašín ${ }^{1}$, Ladislav Bumba ${ }^{1} \mathbb{}{ }^{1}$, \\ Andrew R. Gorringe ${ }^{2} \mathbb{D}$, Frances Alexander ${ }^{2}$ and Peter Šebo ${ }^{1, * \mathbb{D}}$ \\ 1 Institute of Microbiology of the Czech Academy of Sciences, Videnska 1083, 14220 Prague 4, Czech Republic; \\ hejnova@biomed.cas.cz (J.H.); stanek@biomed.cas.cz (O.S.); ludmila.brazdilova@biomed.cas.cz (L.B.); \\ masin@biomed.cas.cz (J.M.); bumba@biomed.cas.cz (L.B.) \\ 2 Public Health England, Research and Development Institute, Porton Down, Salisbury SP4 0JG, UK; \\ andrew.gorringe@phe.gov.uk (A.R.G.); Frances.Alexander@phe.gov.uk (F.A.) \\ * Correspondence: sebo@biomed.cas.cz; Tel.: +420-241-062-762
}

Received: 16 September 2020; Accepted: 29 October 2020; Published: 19 November 2020

\begin{abstract}
Bordetella pertussis whole-cell vaccines $(\mathrm{wP})$ caused a spectacular drop of global pertussis incidence, but since the replacement of wP with acellular pertussis vaccines $(\mathrm{aP})$, pertussis has resurged in developed countries within 7 to 12 years of the change from wP to aP. In the mouse infection model, we examined whether addition of further protective antigens into the aP vaccine, such as type 2 and type 3 fimbriae (FIM2/3) with outer membrane lipooligosaccharide (LOS) and/or of the adenylate cyclase toxoid (dACT), which elicits antibodies neutralizing the CyaA toxin, could enhance the capacity of the aP vaccine to prevent colonization of the nasal mucosa by B. pertussis. The addition of the toxoid and of the opsonizing antibody-inducing agglutinogens modestly enhanced the already high capacity of intraperitoneally-administered aP vaccine to elicit sterilizing immunity, protecting mouse lungs from B. pertussis infection. At the same time, irrespective of FIM2/3 with LOS and dACT addition, the aP vaccination ablated the natural capacity of $\mathrm{BALB} / \mathrm{c}$ mice to clear $B$. pertussis infection from the nasal cavity. While $\mathrm{wP}$ or sham-vaccinated animals cleared the nasal infection with similar kinetics within 7 weeks, administration of the aP vaccine promoted persistent colonization of mouse nasal mucosa by B. pertussis.
\end{abstract}

Keywords: Bordetella pertussis; whooping cough; vaccines; nasal colonization

\section{Introduction}

The Gram-negative coccobacillus Bordetella pertussis is the major agent of a highly contagious respiratory infectious disease called whooping cough [1]. Pertussis pneumonia elicited by B. pertussis and accompanied by hyperleukocytosis and other systemic effects of the pertussis toxin used to be the prime cause of infant mortality in developed countries in the pre-vaccine era. Introduction of effective pertussis vaccines containing killed whole B. pertussis cells (wP), formulated into a diphtheria-tetanus-whole-cell pertussis (DTwP) combination vaccine with the diphtheria and tetanus toxoids, enabled a spectacular reduction of clinical pertussis incidence since the 1950s [2]. Nevertheless, pertussis remains the least-controlled vaccine-preventable infectious disease that was estimated to have accounted for over 24 million of whooping cough cases and more than 160,000 deaths due to pertussis world-wide in 2014 [3]. Moreover, in the past two decades, the highly effective but reactogenic wP vaccines have been progressively replaced in the most developed countries by less reactogenic acellular pertussis (aP) vaccines [2]. These comprise 1 to 5 purified antigens and are typically administered in a pediatric hexavaccine combination. Clinical evidence accumulated over the past decade shows that aP 
vaccines efficiently prevent infant mortality, but confer a substantially less complete and shorter lasting protection from whooping cough, which is further reduced by subsequent Tdap (tetanus toxoid plus a reduced dose of the diphtheria and pertussis vaccine) booster immunizations [4-10]. Consequently, pertussis resurged and whooping cough outbreaks have reappeared in the most developed countries within 7 to 12 years from completion of the change from $\mathrm{wP}$ to aP vaccines. This phenomenon is currently potentiated by the aP vaccine-driven emergence of $B$. pertussis strains that do not produce pertactin (PRN), the key antigenic target of opsonizing antibodies elicited by the aP vaccines [11-15]. While increased surveillance and more accurate diagnostic technologies also contributed to increased reporting of pertussis [16,17], transmission of $B$. pertussis by asymptomatic and/or non-diagnosed aP-vaccinated carriers emerges as a major factor of pertussis resurgence. A growing body of evidence indicates that the aP vaccines fail to prevent nasopharynx infection and B. pertussis transmission in fully vaccinated populations [18,19].

Early seminal work of Mills and Redhead (1993) uncovered the involvement of Th1-polarized $\mathrm{CD}^{+} \mathrm{T}$ cells in elimination of $B$. pertussis infection and pointed to the difference of Th1 polarization of immune responses elicited by the $\mathrm{wP}$ vaccine or experimental infection, as compared to predominant Th2 polarization of immune responses triggered by the aP vaccine in mice [20,21]. Further work revealed that natural infection and the $\mathrm{WP}$ vaccine, but not the aP vaccine, induce $B$. pertussis-specific IL-17 and IFN- $\gamma$-secreting $\mathrm{CD}_{103}{ }^{+} \mathrm{CD} 44^{+} \mathrm{CD} 9^{+} \mathrm{CD}^{+}$tissue resident memory $\mathrm{T}$ cells $\left(\mathrm{T}_{\mathrm{RM}}\right)$ that appear to play a key role in early protection of the airway mucosa from B. pertussis infection $[19,22-28]$.

${ }_{\mathrm{wP}}$ and $\mathrm{aP}$ vaccines also differ substantially in the breadth of antibodies induced, and wP contains innate memory-activating TLR ligands [29,30]. The wP vaccine delivers many bacterial surface antigens, including type 2 and type 3 fimbriae (FIM2/3) and lipooligosaccharide (LOS), both targeted by protective agglutinating and opsonizing serum antibody responses that represent the only as yet clinically established correlate of protection from pertussis illness in humans [31]. In contrast, the protection provided by $\mathrm{aP}$ vaccines against critical pertussis bronchopneumonia mainly relies on induction of serum antibodies that neutralize pertussis toxin (PT) and prevent its systemic effects, such as the life-threatening hyperleukocytosis that contributes to refractory pulmonary hypertension and heart failure [32]. Depending on composition, aP vaccines also induce serum IgG antibodies against $B$. pertussis adhesins, such as PRN, filamentous hemagglutinin (FHA), or FIM2/3.

For historical reasons, the other key immunosuppressive toxin of B. pertussis, the adenylate cyclase toxin-hemolysin (adenylate cyclase toxin (ACT), AC-Hly or CyaA), has not been targeted by licensed aP vaccine formulations. The protective antigen potential of the toxoid of ACT (dACT) contaminated by Escherichia coli LPS (lipopolysaccharide) has previously been established in BALB/C mice $[33,34]$. dACT was also protective when used as LPS-free antigen [35], and its capacity to enhance the protective efficacy of a 1/8 diluted aP vaccine (Infanrix ${ }^{\circledR}$ ) in the model of mouse lung infection by $B$. pertussis was demonstrated in NIH mice [36]. Moreover, under quite different experimental conditions, theRTX (repeats in toxin) fragment of ACT was also found to enhance the protective efficacy of $1 / 80$ diluted (Infanrix ${ }^{\circledR}$ ) vaccine in CD-1 mice [37]. Given that ACT ablates the sentinel bactericidal functions of host neutrophils and macrophage cells [38-40], we reasoned that induction of ACT-neutralizing antibodies by a dACT-supplemented aP vaccine might enable the aP vaccine to elicit protection against nasal colonization by B. pertussis. The results reported here confirm that inclusion of dACT into a FIM2/3 and LOS-supplemented diluted aP vaccine modestly enhances its already high capacity to elicit sterilizing immunity in mouse lungs and protect them from $B$. pertussis infection. However, dACT and FIM2/3 with LOS addition did not override the $\mathrm{aP}$ vaccine-induced inhibition of clearance of $B$. pertussis infection from the nasal cavity of BALB/c mice. 


\section{Materials and Methods}

\subsection{B. pertussis Strains and Growth Conditions}

The Tohama I-derived B. pertussis strain BPSM $\left(\operatorname{Str}^{\mathrm{R}}\right)$ was a kind gift of C. Locht (Institut Pasteur de Lille, Lille, France). The bacteria were grown on Bordet-Gengou (BG) agar plates (Difco, Franklin Lakes, NJ, USA) supplemented with 1\% glycerol, 15\% defibrinated sheep blood (LabMediaServis, Jaromer, Czech Republic) and $100 \mu \mathrm{g} / \mathrm{mL}$ streptomycin at $37^{\circ} \mathrm{C}$ in a $5 \% \mathrm{CO}_{2}$ atmosphere for $72 \mathrm{~h}$ to visualize hemolysis. Liquid cultures were obtained by growing bacteria overnight in modified Stainer-Scholte medium (SSM) [41] supplemented with $3 \mathrm{~g} / \mathrm{L}$ of Casamino Acids (Difco, Franklin Lakes, NJ, USA) and $1 \mathrm{~g} / \mathrm{L}$ of heptakis (2.6-di-O-dimethyl) $\beta$-cyclodextrin (Sigma-Aldrich, St. Louis, MO, USA) to a mid-exponential phase $\left(B\right.$. pertussis $\left.\mathrm{OD}_{600}=1.0\right)$ at $37^{\circ} \mathrm{C}$. Bacterial suspensions were diluted in SSM to the density required for intranasal inoculation. To check for viable colony forming units (CFUs) in the inocula, serially diluted suspensions were plated on BG agar containing streptomycin $(100 \mu \mathrm{g} / \mathrm{mL})$.

The mScarlet fluorescent protein [42] was expressed in B. pertussis Tohama I from the pBBR1MCS [43] derived plasmid carrying the mScarlet gene under the control of the B. pertussis fha promoter.

\subsection{Antigens}

The native PT and PRN antigens were a kind gift of Dr. Umesh Shaligram from Serum Institute of India Pvt. Ltd. (SIIPL, Pune, India). Native FIM2/3 and FHA and recombinant dACT (188GS189) were purified as described previously [44-46]. Native PRN for addition into the diluted Hexacima ${ }^{\circledR}$ vaccine was obtained from NIBSC (Hertfordshire, UK, cat. \# 18/154), and native PRN for ELISA was from SIIPL.

Recombinant 6xHis-tagged rPRN for use in splenocyte restimulation was produced in E. coli BL21 cells and purified from urea extracts of inclusion bodies by Ni-NTA agarose chromatography including an endotoxin removal step by washing the resin with bound PRN with 1\% of Triton X100 [45]. Purified rPRN was dialyzed against $8 \mathrm{M}$ urea in $50 \mathrm{mM}$ Tris $\mathrm{pH}$, and the homogeneity of the protein was analyzed by SDS-PAGE. The endotoxin content was determined with a Limulus amebocyte lysate assay (QCL-1000, Lonza, Walkersville, MD, USA).

\subsection{Composition of Vaccines Used in the Study}

All vaccines used in this study were formulated into $200 \mu \mathrm{L}$ doses with the antigen content described in Table 1 and were admixed no longer than $1 \mathrm{~h}$ before the administration. The commercial aP-containing pediatric hexavaccines (D/T/aP/Hib/HepB/IPV) used in this study were Hexacima ${ }^{\circledR}$ (Sanofi Pasteur S.A., Lyon, France) and Infanrix ${ }^{\circledR}$ (GlaxoSmithKline Biologicals S.A., London, UK). The wP-containing pediatric pentavaccine $(\mathrm{D} / \mathrm{T} / \mathrm{wP} / \mathrm{Hib} / \mathrm{HepB})$ used was Pentavac ${ }^{\circledR} \mathrm{SD}$ (Serum Institute of India PVT. LTD.). Aliquots of the commercial vaccines were diluted in phosphate-buffered saline (PBS) with alum adjuvant at a final concentration of $0.208 \% \mathrm{Al}(\mathrm{OH})_{3}(w / v)$, so that $1 / 160$ human dose (HD) $\left(\right.$ Hexacima ${ }^{\circledR}$ ) aP, or $1 / 20$ HD (Hexacima ${ }^{\circledR}$ or Infanrix ${ }^{\circledR}$ ) aP, or $1 / 4$ HD (Pentavac ${ }^{\circledR}$ SD) wP was contained in $200 \mu \mathrm{L}$. The $200 \mu \mathrm{L}$ doses of the supplemented aP vaccines further contained the indicated amounts 1,3, or $5 \mu \mathrm{g} /$ dose of added fimbriae 2/3 (FIM2/3) and of associated LOS (6000, 18,000 and 30,000 endotoxin units (EU), respectively), and/or a $0.2 \mu \mathrm{g} / \mathrm{dose}$ of added PRN (into 1/20 HD of Hexacima ${ }^{\circledR}$ only) and/or $30 \mu \mathrm{g} / \mathrm{dose}$ of $\mathrm{dACT}$ (Table 1). The unvaccinated control mice received $200 \mu \mathrm{L}$ of PBS with $0.208 \% \mathrm{Al}(\mathrm{OH})_{3}(w / v)$.

\subsection{Ethics Statement}

All animal experiments were approved by the Animal Welfare Committee of the Institute of Molecular Genetics of the Czech Academy of Sciences, v. v. i., in Prague, Czech Republic. Handling of animals was performed according to the Guidelines for the Care and Use of Laboratory Animals, the Act of the Czech National Assembly, Collection of Laws no. 246/1992. Permission no. 37/2018 was issued 
by the Animal Welfare Committee of the Institute of Molecular Genetics of the Czech Academy of Sciences in Prague.

Table 1. Composition of the used vaccines.

\begin{tabular}{|c|c|c|c|c|c|c|c|c|}
\hline Vaccine & Brand Name & $\begin{array}{l}\mathrm{dPT} \\
(\mu \mathrm{g})\end{array}$ & $\begin{array}{l}\text { FHA } \\
(\mu \mathrm{g})\end{array}$ & $\begin{array}{l}\text { PRN } \\
(\mu g)\end{array}$ & $\begin{array}{c}\text { FIM2/3 } \\
\text { ( } \mu \mathrm{g})\end{array}$ & $\begin{array}{l}\text { LOS } \\
\text { (EU) }\end{array}$ & $\begin{array}{c}\text { dACT } \\
(\mu g)\end{array}$ & $\begin{array}{l}\mathrm{Al}^{3+} \\
(\mu \mathrm{g})\end{array}$ \\
\hline 1/160 aP Hex & \multirow{5}{*}{ Hexacima ${ }^{\circledR}$} & 0.156 & 0.156 & - & - & & - & \multirow{5}{*}{137} \\
\hline 1/160 aP Hex + FIM2/3 (1 $\mu \mathrm{g})$ & & 0.156 & 0.156 & - & 1 & 6000 & - & \\
\hline 1/160 aP Hex + FIM2/3 (3 $\mu \mathrm{g})$ & & 0.156 & 0.156 & - & 3 & 18,000 & - & \\
\hline 1/160 aP Hex + FIM2/3 $(1 \mu \mathrm{g})+\mathrm{dACT}$ & & 0.156 & 0.156 & - & 1 & 6000 & 30 & \\
\hline 1/160 aP Hex + FIM2/3 $(3 \mu \mathrm{g})+\mathrm{dACT}$ & & 0.156 & 0.156 & - & 3 & 18,000 & 30 & \\
\hline $1 / 20 \mathrm{aP} \mathrm{Hex}$ & \multirow{3}{*}{ Hexacima $^{\circledR}$} & 1.25 & 1.25 & - & - & & - & \multirow{3}{*}{153} \\
\hline 1/20 aP Hex + FIM2/3 + PRN & & 1.25 & 1.25 & 0.2 & 5 & 30,000 & - & \\
\hline $1 / 20 \mathrm{aP} H e x+\mathrm{FIM} 2 / 3+\mathrm{PRN}+\mathrm{dACT}$ & & 1.25 & 1.25 & 0.2 & 5 & 30,000 & 30 & \\
\hline $1 / 20 \mathrm{aP}$ Inf & \multirow{3}{*}{ Infanrix ${ }^{\circledR}$} & 1.25 & 1.25 & 0.4 & - & & - & \multirow{3}{*}{131} \\
\hline $1 / 20 \mathrm{aP}$ Inf + FIM2/3 & & 1.25 & 1.25 & 0.4 & 5 & 30,000 & - & \\
\hline $1 / 20 \mathrm{aP}$ Inf + FIM $2 / 3+\mathrm{dACT}$ & & 1.25 & 1.25 & 0.4 & 5 & 30,000 & 30 & \\
\hline $1 / 4 \mathrm{wP}$ Penta & Pentavac ${ }^{\circledR}$ SD & nd & nd & nd & nd & nd & nd & $\leq 312$ \\
\hline
\end{tabular}

dACT, detoxified adenylate cyclase toxin (188GS189); dPT, detoxified pertussis toxin; FHA, filamentous hemagglutinin; FIM2/3, fimbriae types 2 and 3; Hex, Hexacima ${ }^{\circledR}$; Inf, Infanrix ${ }^{\circledR}$; LOS, lipooligosaccharide; EU, endotoxin unit; Penta, Pentavac ${ }^{\circledR}$; PRN, pertactin; nd-not determined.

\subsection{Mouse Immunization and Intranasal Infection}

Female BALB/cByJ mice (Charles River, Écully, France) were vaccinated by intraperitoneal injection at 5 weeks of age with the vaccines described in Table 1 and were boosted with the same vaccine 14 days later. Control mice received PBS with alum $\left(0.208 \% \mathrm{Al}(\mathrm{OH})_{3}(w / v)\right)$. Three weeks later, six mice from each group were withdrawn for serological analysis and for splenocyte isolation and restimulation (see below). Remaining immunized mice were anesthetized by intraperitoneal (i.p.) injection of ketamine $(80 \mathrm{mg} / \mathrm{kg})$ and xylazine $(8 \mathrm{mg} / \mathrm{kg})$ in $0.9 \%$ saline and challenged intranasally by the indicated bacterial dose applied in two aliquots of $10 \mu \mathrm{L}$ per nare of the mouse. Three to six mice per group were anesthetized as described above at the indicated time points (e.g., at $2 \mathrm{~h}, 7,14$, 27,35 and 50 days post challenge). For ethical reasons (3R requirements), three mice per group were used in the ex-post control of the inoculated dose (the first time point of $2 \mathrm{~h}$ ) and at time points where no or very low CFU counts were expected based on preliminary data. Groups of 5 or 6 mice were sacrificed and analyzed at the other time points for comparisons between individual vaccine groups and to the control mice group. Lungs and nasal cavities with turbinates were aseptically removed and homogenized in physiological saline with tissue grinders (Heidolph mechanical stirrers, Model RZR 2020, Merck, Darmstadt, Germany) and tissue homogenizer (IKA Ultra turrax T25, Sigma-Aldrich, St. Louis, MO, USA), respectively. Nasal homogenates were cleared by centrifugation for $10 \mathrm{~min}$ at $900 \mathrm{rpm}(217 \times g)$, and dilutions of lung and nasal homogenates were plated on BG agar supplemented with $15 \%$ defibrinated sheep blood and $100 \mu \mathrm{g} / \mathrm{mL}$ of streptomycin. CFU were counted after incubation for 4 days at $37^{\circ} \mathrm{C}$.

\subsection{Analysis of Antibody Responses}

Blood was collected from anesthetized animals by retro-orbital puncture. Serum was separated by centrifugation at $5000 \times \mathrm{g}$ for $10 \mathrm{~min}$ at $8{ }^{\circ} \mathrm{C}$ and stored at $-80{ }^{\circ} \mathrm{C}$ until use. Antibodies to B. pertussis antigens were determined by ELISA as described by van der Ark et al. [47]. Briefly, wells of ThermoFisher Nunc Maxisorp 96-well plates were coated overnight with $0.5 \mu \mathrm{g}$ of the respective antigens in $100 \mu \mathrm{L}$ of $100 \mathrm{mM}$ carbonate buffer $\mathrm{pH} 9.6$ for PT, FHA, PRN, and FIM2/3 and in $50 \mathrm{mM}$ Tris $\mathrm{pH} 8$ for dACT. For the anti-ACT ELISA, the coating and the washing buffer $(50 \mathrm{mM}$ Tris buffer $\mathrm{pH} 8, \mathrm{pH} 7.4$, respectively) were supplemented with $2 \mathrm{mM} \mathrm{CaCl}_{2}$ to facilitate the folding of the immunodominant RTX domain of the ACT protein.

For determination of total IgG by whole bacterial cell ELISA, plates were coated overnight at $37^{\circ} \mathrm{C}$ with $100 \mu \mathrm{L}$ of $B$. pertussis cells diluted to $\mathrm{OD}_{600}$ of 0.025 in PBS. The wells were blocked with 
$200 \mu \mathrm{L}$ of PBS with $1 \%$ BSA. Ten-fold serial dilutions of sera $(100 \mu \mathrm{L})$ were added starting at 1:10 dilution for control mouse sera and 1:100 for vaccinated mouse sera. Secondary antibodies labelled with horseradish peroxidase were used $(100 \mu \mathrm{L})$. Upon reaction of the added OPD and $\mathrm{H}_{2} \mathrm{O}_{2}, \mathrm{~A}_{492}$ was read. For titration of total IgG, sheep anti-mouse antibody (GE, Chicago, IL, USA, clone NA931V) was used at dilution 1:3000. For titration of IgG1 isotype, goat anti-mouse antibody (Invitrogen, Carlsbad, CA, USA, cat. n. A10551, polyclonal) was used at dilution of 1:1000. For titration of IgG2a isotype, goat anti-mouse antibody (Abcam, Cambridge, UK, cat. n. ab97245, polyclonal) was used at dilution of 1:50,000. Antibody titers were calculated from the inflection points of the titration curves.

\subsection{Opsonophagocytic Uptake}

The opsonophagocytic uptake assay (OPA) was adapted from Fabbrini et al. [48] using HL-60 cells. Briefly, HL-60 cells were differentiated for 5 days in $60 \mathrm{~mL}$ volumes of Roswell Park Memorial Institute medium (RPMI 1640; Sigma-Aldrich, St. Louis, MO, USA) supplemented with $10 \%(v / v)$ FBS and $1.25 \%(v / v)$ DMSO, at an initial cell concentration of $4 \times 10^{5} \mathrm{~mL}$. Cell differentiation status was verified by flow cytometry using a FITC-labeled anti-CD11b antibody (OKM1 clone). The cells were washed in Hank's Balanced Salt Solution (HBSS)with $1 \%$ BSA and $0.1 \%$ glucose but devoid of $\mathrm{Ca}^{2+}$ and $\mathrm{Mg}^{2+}$ and resuspended in HBSS with $\mathrm{Ca}^{2+}$ and $\mathrm{Mg}^{2+}$ plus $1 \%$ BSA and $0.1 \%$ glucose.

Serum samples were split in two aliquots, and in one aliquot, the complement was heat-inactivated for $30 \mathrm{~min}$ at $56^{\circ} \mathrm{C}$. Both heat-inactivated and untreated sera were used in the opsonophagocytic assays for comparison.

B. pertussis expressing the mScarlet fluorescent protein was grown overnight in Steiner-Scholte medium at $37^{\circ} \mathrm{C}$. The bacteria $\left(5 \times 10^{6}\right.$ cells/well $)$ were opsonized in a total volume of $50 \mu \mathrm{L}$ of complete HBSS with $1 \%$ BSA and $0.1 \%$ glucose upon addition of $5 \mu \mathrm{L}$ of tested sera $(10 \%)$ for 30 min at $37{ }^{\circ} \mathrm{C}$ with agitation. A total of $10^{5}$ differentiated HL-60 cells in $50 \mu \mathrm{L}$ were added to each well, diluting the serum to $5 \%$. Cells were incubated with bacteria for $30 \mathrm{~min}$ at $37^{\circ} \mathrm{C}$ with agitation. Uptake was stopped by the addition of $100 \mu \mathrm{L}$ of ice-cold PBS, and the cells were washed, stained with FITC-labeled anti-CD11b (OKM1 clone) antibody, washed twice, resuspended in $100 \mu \mathrm{L}$ of ice-cold PBS and kept on ice until analyzed by flow cytometry. Only CD11 bigh cells were included in the analysis by the gating strategy. Mean fluorescence intensity (MFI) of the ingested bacteria was measured. Data from individual experiments were normalized to the control (opsonization with naïve serum of control mice).

\subsection{Agglutination Titer Determination}

Agglutination titer of the sera was measured using the agglutination reagents (TestLine Clinical Diagnostics, Brno, CZ), according to the manufacturer's instructions. Briefly, a two-fold dilution series of each serum in physiological saline solution in U-bottom wells was set up, and equal volumes of the agglutinogen (standardized inactivated B. pertussis suspension) were added. The starting dilution was 1:4, and the final dilution was 1:8192. A serum with known agglutinating titer from the same manufacturer was used as a positive control, and physiological saline solution was used as a negative control. The samples were incubated for $2.5 \mathrm{~h}$ in $37^{\circ} \mathrm{C}$ humidified atmosphere and further incubated overnight $(18 \mathrm{~h})$ at $20^{\circ} \mathrm{C}$. A homogenous agglutinate marked a positive reaction, while sediment at the bottom of the well marked a negative reaction. The titer was determined as the last dilution yielding a homogenous agglutinate. The agglutination assays were repeated three times.

\subsection{Splenocyte Restimulation and Secreted Cytokine Determination}

Gently disrupted spleens were homogenized by passage through a strainer. Splenocyte suspensions were depleted of erythrocytes by treatment with ammonium chloride-potassium, washed twice and cultured in RPMI 1640 medium with L-glutamine supplemented with 10\% FCS, 1\% penicillin and $1 \%$ streptomycin at $3 \times 10^{5}$ cells/well in 96-well flat-bottomed tissue culture plates. Spleen cells from mice immunized with the $\mathrm{wP}$ vaccine were cultured (stimulated) in a total volume of $200 \mu \mathrm{L}$ per well with $3 \times 10^{6}$ heat-killed B. pertussis BPSM cells (MOI 1:10). Spleen cells from mice immunized 
with the aP vaccine were stimulated in a total volume of $200 \mu \mathrm{L}$ per well with the combinations of antigens (e.g., urea denatured PT, native FHA, rPRN, native FIM2/3 and dACT) in combinations reflecting the aP vaccine compositions used, $2 \mu \mathrm{g} / \mathrm{mL}$ of detoxified pertussis toxin (dPT), FHA or FIM2/3, $5 \mu \mathrm{g} / \mathrm{mL}$ of $\mathrm{rPRN}$ and $1 \mu \mathrm{g} / \mathrm{mL}$ of $\mathrm{dACT}$, respectively. PBS and phorbol myristate acetate (PMA)/ionomycin (eBiosciences, Sigma-Aldrich, St. Louis, MO, USA) served as negative and positive controls, respectively. Splenocyte cultures were incubated at $37{ }^{\circ} \mathrm{C}$ in $5 \% \mathrm{CO}_{2}$ atmosphere at $90 \%$ humidity for 48 and $72 \mathrm{~h}$. Cell viability was checked by Trypan blue exclusion before and after the incubation.

Cytokine concentrations in splenocyte culture supernatants were determined using a custom built ProcartaPlex cytokine bead assay (ThermoFisher Scientific, Waltham, MA, USA) on a Bio-Plex 200 instrument (Bio-Rad, Hercules, CA, USA) according to the manufacturer's instructions. The instrument was calibrated on assay days using a Bio-Plex Calibration kit (Bio-Rad, \#171,203,060), and data were validated using a Bio-Plex Validation kit (Bio-Rad, \#171,203,001) within two weeks of each assay.

\subsection{ACT Cytotoxicity Neutralization Assay}

THP-1 cells were cultured at $37^{\circ} \mathrm{C}$ in a humidified air/CO $/ \mathrm{CO}_{2}$ atmosphere in RPMI medium supplemented with $10 \%$ heat-inactivated FCS, penicillin $(100$ i.u. $/ \mathrm{mL})$, streptomycin $(100 \mu \mathrm{g} / \mathrm{mL})$ and amphotericin B (250 ng/mL). Prior to assays, RPMI was replaced with Dulbecco's Modified Eagle's Medium (D-MEM) $\left(1.9 \mathrm{mM} \mathrm{Ca}^{2+}\right)$ without FCS.

For neutralization of ACT binding to THP-1 cells, intact ACT $(1 \mu \mathrm{g} / \mathrm{mL})$ was preincubated in D-MEM medium (without FCS) for $15 \mathrm{~min}$ on ice in the presence of the 1:50 diluted mouse serum before THP- 1 cells $\left(10^{6}\right)$ were added and the mixture was incubated for an additional $30 \mathrm{~min}$ at $4{ }^{\circ} \mathrm{C}$. Unbound ACT toxin was removed by three washes in D-MEM, and upon transfer to a fresh tube, the cells were lyzed with $0.1 \%$ Triton X-100 for determination of the cell-bound AC enzyme activity. ACT binding in the presence of naïve serum was taken as $100 \% . n=4$ biological replicates performed in duplicates.

For neutralization of the cytotoxic activity, ACT $(125-1000 \mathrm{ng} / \mathrm{mL})$ was incubated with serum samples (dilution 1:50) for $15 \mathrm{~min}$ at room temperature in D-MEM medium, and the samples were added to the THP-1 monocyte/macrophage cells $\left(1.5 \times 10^{5}\right)$. Cells were incubated at $37^{\circ} \mathrm{C}$ for $2 \mathrm{~h}$ in a humidified air $/ 5 \% \mathrm{CO}_{2}$ atmosphere, and the number of viable cells was determined using the Cell proliferation reagent kit WST-1 (Roche Applied Science, Penzberg, Germany), based on the conversion of the tetrazolium salt WST-1 (4-[3-(4-Iodophenyl)-2-(4-nitro-phenyl)-2H-5-tetrazolio]-1,3-benzene sulfonate) to formazan product $\left(\mathrm{A}_{450 \mathrm{~nm}}\right)$. The viability of control cells (buffer treated only) was taken as $100 \% . n=2$ biological replicates performed in duplicates.

\subsection{Statistical Analysis}

Statistical analysis was carried out using the algorithms incorporated in the GraphPad Prism 7 package. Two-way analysis of variance (ANOVA) followed by Tukey's multiple comparison test was used to analyze the statistical significance between groups. $p$ values of less than 0.05 were considered statistically significant. ${ }^{*}(p<0.05) ;{ }^{* *}(p<0.01) ;{ }^{* * *}(p<0.001) ;{ }^{* * * *}(p<0.0001)$.

\section{Results}

3.1. Limiting Dose of aP Supplemented with $\mathrm{AACT}$ and FIM2/3 Plus LOS Elicits Partial Protective Immunity against B. pertussis Infection of Mouse Lungs But No Protection of the Nasal Cavity

We first sought to define the fraction of a human dose (HD) of the aP vaccine that would allow detection of an added protective activity of the dACT toxoid, and/or of the added FIM2/3 and LOS antigens, against colonization of the nasal mucosa and of mouse lungs. Several challenge doses delivered in various volumes were tested in preliminary experiments, and the dose of $10^{6} \mathrm{~B}$. pertussis 
$\operatorname{BPSM}\left(\right.$ Str $^{\mathrm{R}}$, Tohama I-derived) CFU delivered in $2 \times 10 \mu \mathrm{L}$ into the nares of mice was chosen to achieve a high enough CFU number retained in the nasal cavity. This inoculum enabled reliable CFU counting in homogenates of the nasal tissue, as well reliable colonization tracking in the lungs, where a clear increase in CFU was observed in the control animals within the first 7 days of infection (Figure 1a). Preliminary titration of the vaccine dose (Figure S1) indicated that a 1/160 HD, containing $0.156 \mu \mathrm{gPT}$ and $0.156 \mu \mathrm{g}$ FHA in PBS with alum $\left(\mathrm{Al}(\mathrm{OH})_{3} \quad 0.208 \% w / v\right)$ and injected intraperitoneally twice at two week intervals, conferred a still statistically significant, but already sufficiently low level of protection against mouse lung infection by intranasal application of $10^{6}$ CFU of B. pertussis BPSM. As shown in Figure 1a, at this aP vaccine dose, there was only about a five-fold difference in the CFU counts recovered on day 7 after infection from lungs of sham-vaccinated mice that received PBS with alum and mice vaccinated twice with $1 / 160 \mathrm{HD}$ of Hexacima ${ }^{\circledR}$ aP vaccine diluted in PBS with alum. Addition of 1 or $3 \mu \mathrm{g}$ of FIM2/3 antigen containing 6000 or 18,000 EU of B. pertussis LOS per dose of such vaccine, respectively, improved the protection slightly, yielding about five-fold reduction of bacterial load in infected lungs compared to $1 / 160 \mathrm{HD}$ of the aP vaccine only (ten-fold compared to control). However, the difference was not enhanced any further upon addition of $30 \mu \mathrm{g}$ of the LPS-free dACT toxoid per vaccine dose. Moreover, as shown in Figure 1b, the 1/160 HD of aP did not on its own confer any protection against bacterial colonization of the mouse nose. Only about a two-fold decrease in bacterial burden in the nose was observed when the diluted aP was supplemented with FIM2/3 and LOS antigens alone, or in combination with dACT. In these experiments, the 1/160 HD of aP supplemented with dACT alone was not tested, as anti-ACT antibodies are proposed to improve efficacy only when opsonizing antibodies are induced and no such antigen is contained in the PT + FHA-containing aP (Hexacima $\left.{ }^{\circledR}\right)$ vaccine.
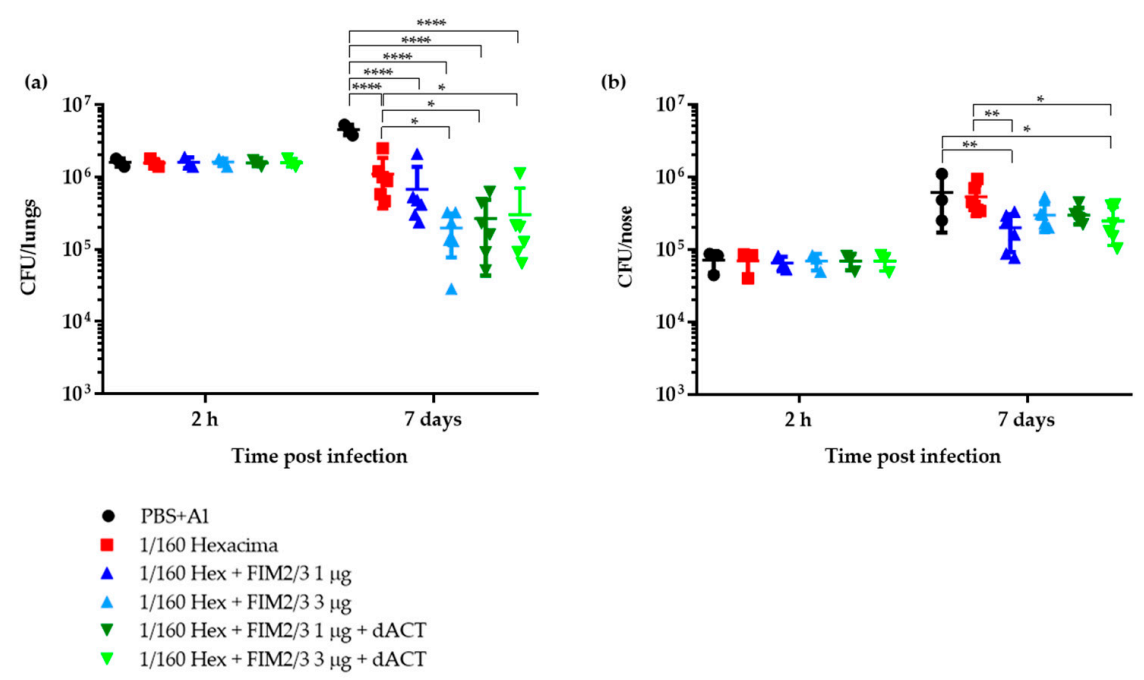

Figure 1. Protection against intranasal B. pertussis challenge in BALB/c mice immunized by $1 / 160$ human dose (HD) of antigen-supplemented Hexacima ${ }^{\circledR}$ aP vaccine. Mice were immunized intraperitoneally on days 0 and 14 with $1 / 160 \mathrm{HD}$ of the aP vaccines $\left(1 / 160\right.$ HD Hexacima ${ }^{\circledR}, 1 / 160$ HD Hexacima $^{\circledR}+$ FIM2/3 $(1 \mu \mathrm{g}), 1 / 160$ HD Hexacima ${ }^{\circledR}+$ FIM2/3 $(3 \mu \mathrm{g}), 1 / 160$ HD Hexacima ${ }^{\circledR}+$ FIM2/3 $(1 \mu \mathrm{g})+$ dACT $(30 \mu \mathrm{g})$ and 1/160 HD Hexacima ${ }^{\circledR}+$ FIM2/3 $\left.(3 \mu \mathrm{g})+\mathrm{dACT}(30 \mu \mathrm{g})\right)$. Mice injected with phosphate-buffered saline (PBS) + alum $(0.208 \% w / v)$ served as negative controls. Mice were challenged intranasally with B. pertussis BPSM $\left(1.4 \times 10^{6} \mathrm{CFU}\right.$ in $\left.2 \times 10 \mu \mathrm{L}\right)$ on day 35 . Mice were sampled at day $0+2 \mathrm{~h}$ and day 7 post challenge for enumeration of bacteria in the lungs (a) and in the nasal cavity (b). Results represent the bacterial counts for three to six mice per group \pm SD. Two-way ANOVA followed by Tukey's multiple comparison test was used to analyze the statistical significance between groups. Only significant differences are indicated. ${ }^{*}(p<0.05) ;{ }^{* *}(p<0.01) ;{ }^{* * *}(p<0.0001)$. 
3.2. 1/20 Human Dose of dPT + FHA aP Vaccine Supplemented with PRN and FIM2/3 Induces Sterilizing Immunity in Mouse Lungs But Inhibits Elimination of B. pertussis Infection from the Nasal Cavity

The concentration of the aP vaccine was raised to $1 / 20 \mathrm{HD}$ (e.g., $1.25 \mu \mathrm{g}$ dPT and $1.25 \mu \mathrm{g}$ FHA per dose) and a limiting amount $(0.2 \mu \mathrm{g}$ per dose) of the potent opsonizing antibody-inducing antigen PRN was added. We supposed that neutralization of the phagocyte activity-ablating action of ACT by the dACT-induced neutralizing antibodies (Figure S2a) would observably potentiate the impact of the presence of opsonizing anti-PRN antibodies. As indeed shown in Figure 2a, compared to the PBS with alum control, two doses of the $1 / 20 \mathrm{HD}$ of aP vaccine alone (Hexacima ${ }^{\circledR}$ diluted in PBS with alum) conferred only a modest protection of mouse lungs against a challenge with $3.4 \times 10^{6} \mathrm{CFU}$ of BPSM bacteria delivered into mouse nares in $2 \times 10 \mu \mathrm{L}$. However, the use of such a modified vaccine did not enable bacterial clearance to occur much faster than in control animals and took 21 days to complete. In contrast, supplementation of the $1 / 20 \mathrm{HD}$ of the aP vaccine with $5 \mu \mathrm{g}$ per dose of FIM2/3 and 30,000 EU of LOS and with $0.2 \mu \mathrm{g}$ PRN per vaccine dose brought about a significant enhancement of the protective immunity and yielded complete clearance of $B$. pertussis from mouse lungs within 7 days after infection. Intriguingly, the potency of the FIM2/3 and PRN-supplemented 1/20 HD aP vaccine was rather compromised by further addition of $30 \mu \mathrm{g}$ per dose of LPS-free dACT. Even more intriguingly, neither 1/20 HD of the $\mathrm{aP}$, nor its antigen-supplemented versions, conferred any protection against persistent colonization of the mouse nose (Figure 2b). Compared to sham immunization with PBS with alum $(0.208 w / v)$, only about ten-fold lower bacterial burden was found on day 7 after infection in the noses of mice that received 1/20 HD of aP supplemented with FIM2/3 (5 $\mu \mathrm{g})$, LOS (30,000 EU) and PRN $(0.2 \mu \mathrm{g})$, with or without the addition of $30 \mu \mathrm{g}$ of dACT. Moreover, all mice that received any of the aP vaccine combinations maintained a steady level of nasal colonization at around $10^{5} \mathrm{CFU}$ per nose for at least 35 days after infection. In contrast, the sham-immunized control mice that received PBS with alum essentially cleared the nasal infection by that time.
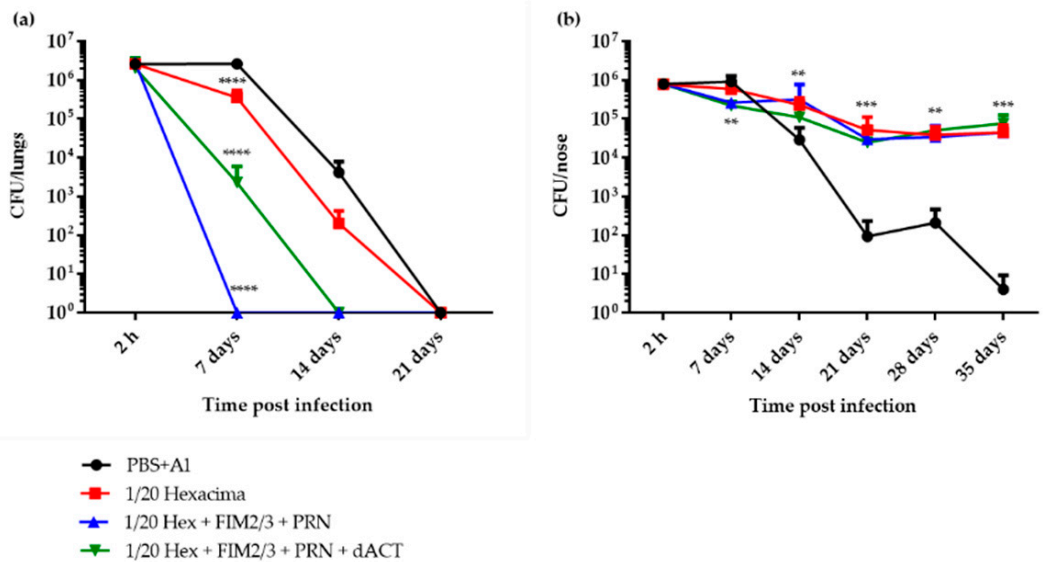

Figure 2. Protection against intranasal B. pertussis challenge in BALB/c mice immunized by $1 / 20 \mathrm{HD}$ of antigen-supplemented Hexacima ${ }^{\circledR}$ aP vaccine. Mice were immunized intraperitoneally on days 0 and 14 with 1/20 HD of aP vaccines (1/20 HD Hexacima ${ }^{\circledR}, 1 / 20$ HD Hexacima ${ }^{\circledR}+$ FIM2/3 (5 $\left.\mu \mathrm{g}\right)$, $1 / 20$ HD Hexacima ${ }^{\circledR}+$ FIM2/3 $(5 \mu \mathrm{g})+$ PRN $(0.2 \mu \mathrm{g})$ and 1/20 HD Hexacima ${ }^{\circledR}+$ FIM2/3 $(5 \mu \mathrm{g})+$ PRN $(0.2 \mu \mathrm{g})+\mathrm{dACT}(30 \mu \mathrm{g})$. Mice injected with PBS + alum $(0.208 \% w / v)$ served as negative controls. Mice were challenged intranasally with B. pertussis BPSM $\left(3.4 \times 10^{6} \mathrm{CFU}\right.$ in $\left.2 \times 10 \mu \mathrm{L}\right)$ on day 35 and sampled at indicated time points $(2 \mathrm{~h}, 7,14,21,28$ and 35 days) post challenge for enumeration of bacteria in the lungs (a) and in the nasal cavity (b). Results represent the means of bacterial counts for three to six mice per group $\pm \mathrm{SD}$, as defined in Materials and Methods. Two-way ANOVA followed by Tukey's multiple comparison test was used to analyze the statistical significance between groups. Only significant differences vs. negative control mice are indicated. ${ }^{* *}(p<0.01) ;{ }^{* *}(p<0.001)$; $* * * *(p<0.0001)$. 
3.3. 1/20 Human Dose of a dPT + FHA + PRN aP Vaccine Supplemented with FIM2/3 and dACT Induces Sterilizing Immunity in Mouse Lungs But Blocks Elimination of B. pertussis Infection from the Nasal Cavity

The intriguing inhibition of nasal clearance of $B$. pertussis infection in mice that received 1/20 HD of the aP vaccine prompted us to reproduce the result with another diluted commercial hexavaccine that contains the same amounts of $\mathrm{dPT}$ and FHA but also contains $8 \mu \mathrm{g}$ of PRN per human dose (Infanrix ${ }^{\circledR}$ ). As shown in Figure 3a, a near identical result was obtained. The 1/20 HD of the aP vaccine alone, containing $0.4 \mu \mathrm{g}$ of PRN per dose, conferred immunity, allowing for a reduction in the bacterial burden in the lungs 7 days post infection that was significant when compared with PBS with alum control, but still on day 14, a comparable bacterial burden in the lungs as in sham-vaccinated animals was observed. The protection conferred by the $1 / 20 \mathrm{HD}$ of aP was importantly enhanced upon addition of $5 \mu \mathrm{g}$ of FIM2/3 and 30,000 EU of LOS per dose and was again slightly lower upon further addition of $30 \mu \mathrm{g}$ of $\mathrm{dACT}$. Both mice groups that received the supplemented aP vaccine cleared the infection from the lungs by day 14 post infection. For comparison, a group of mice immunized with 1/4 HD of a pediatric wP-based pentavaccine (Pentavac ${ }^{\circledR}$ SD) was also used, and the wP-vaccinated group of mice cleared the lung infection within 7 days. Remarkably, despite the rather high rate of lung infection clearance, all aP-immunized mice-irrespective of the addition of FIM2/3 with LOS and/or $\mathrm{dACT}$, and despite the presence of $0.4 \mu \mathrm{g}$ of PRN per vaccine dose and of ACT-neutralizing antibodies (Figure S2b) - again maintained a steady level of $B$. pertussis colonization at $10^{5}$ CFU per nose for 50 days post infection (Figure $3 b$ ).

(a)

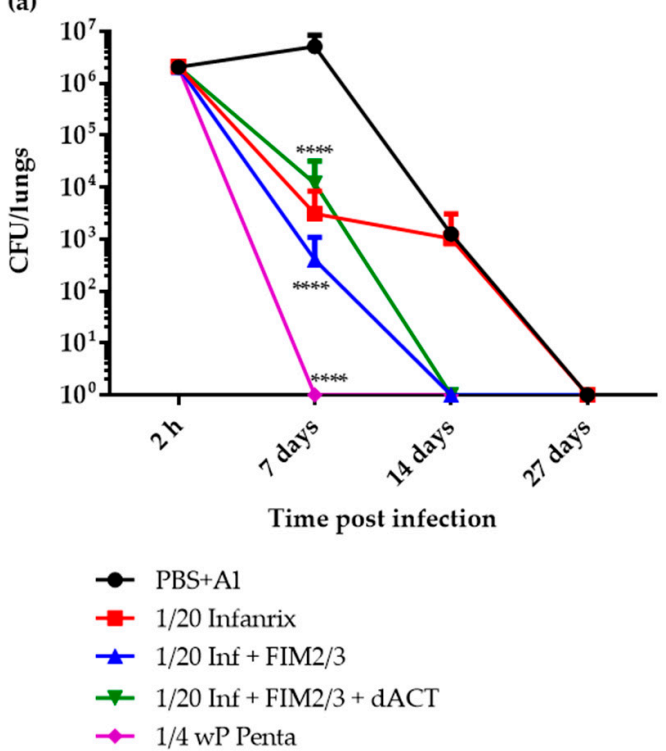

(b)

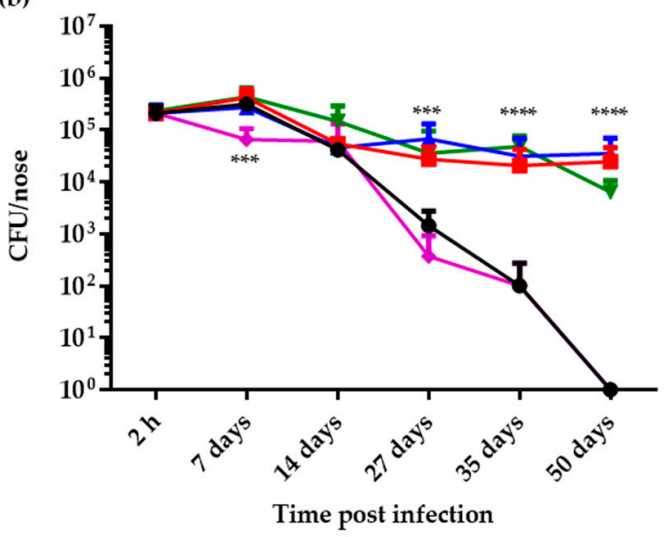

Figure 3. Protection against intranasal B. pertussis challenge in BALB/c mice immunized by $1 / 20 \mathrm{HD}$ of antigen-supplemented Infanrix ${ }^{\circledR}$ aP vaccine. Mice were immunized intraperitoneally on days 0 and 14 with $1 / 4 \mathrm{HD}$ of wP and 1/20 HD of aP vaccines (1/20 HD Infanrix ${ }^{\circledR}, 1 / 20$ HD Infanrix ${ }^{\circledR}+$ FIM2/3 (5 $\left.\mu \mathrm{g}\right)$ and 1/20 HD Infanrix ${ }^{\circledR}+$ FIM2/3 $(5 \mu \mathrm{g})+\mathrm{dACT}(30 \mu \mathrm{g})$. Mice injected with PBS + alum $(0.208 \% w / v)$ served as negative controls. Mice were challenged intranasally with B. pertussis BPSM $\left(2.7 \times 10^{6} \mathrm{CFU}\right.$ in $20 \mu \mathrm{L})$ on day 35 and sampled at indicated time points $(2 \mathrm{~h}, 7,14,27,35$ and 50 days) post challenge for enumeration of bacteria in the lungs (a) and in the nasal cavity (b). Results represent the means of bacterial counts for three to five mice per group \pm SD, as defined in Materials and Methods. Two-way ANOVA followed by Tukey's multiple comparison test was used to analyze the statistical significance between groups. Only significant differences vs. negative control mice are indicated. ${ }^{* * *}(p<0.001)$; $* * * *(p<0.0001)$. 
3.4. The Supplemented aP Vaccine Induces a Th2-Polarized Immune Response with IgG1 Isotype-Agglutinating Antibodies That Enhance Opsonophagocytic Uptake of B. pertussis Bacteria In Vitro

Intriguingly, the failure to clear the infection from the nose was not due to a failure to trigger the expected immune responses. The added antigens elicited production of antibodies that increased opsonophagocytic uptake of mScarlett-expressing B. pertussis BPSM bacteria by differentiated HL-60 cells, as shown in Figure $4 \mathrm{a}$. Moreover, the 1/20 HD of aP (Infanrix ${ }^{\circledR}$ ) supplemented with $5 \mu \mathrm{g}$ of FIM2/3 and 30,000 EU of LOS per dose triggered formation of B. pertussis bacteria-agglutinating serum antibodies at levels as high as the 1/4 HD of a pediatric wP-based pentavaccine (Figure $4 \mathrm{~b}$ ). Hence, a functional antibody response to FIM2/3 and LOS was induced (see also Figure S3). However, the 1/20 HD of aP and the antigen-supplemented 1/20 HD aP induced much lower titers of total IgG against whole $B$. pertussis cells than the vaccination with $1 / 4 \mathrm{HD}$ of the wP vaccine (Figure $4 \mathrm{c}$ ). Furthermore, the antibody responses elicited by the aP vaccine compositions were strongly polarized towards the IgG1 antibody isotype (Figure 4d), and very low titers of IgG2a isotype antibodies recognizing whole $B$. pertussis cells were induced by the $1 / 20 \mathrm{HD}$ of aP vaccines, whether supplemented or not (Figure $4 \mathrm{e})$.

Indeed, compared to splenocytes of wP-vaccinated mice, upon stimulation with the B. pertussis antigens for 48 and $72 \mathrm{~h}$, the total splenocytes of mice immunized with the 1/20 HD of aP supplemented with FIM2/3, LOS and dACT produced significantly less of the Th1 cytokine IFN- $\gamma$ and of TNF- $\alpha$, as well as of the IL-2 cytokines (Figure 5a). Importantly, the IFN- $\gamma$ and TNF- $\alpha$ responses were substantially lower in the aP-vaccinated mice, despite addition of FIM2/3 with LOS, than in sham-vaccinated mice that received only PBS with alum. The same was true also for the IL-6 and IL-10 cytokines, while the IL-17A cytokine secretion by splenocytes of aP-vaccinated mice was increased over that of control mouse splenocytes and, after $72 \mathrm{~h}$ of antigenic stimulation, approached IL-17A levels produced by splenocytes from wP-vaccinated mice (Figure $5 b$ ).

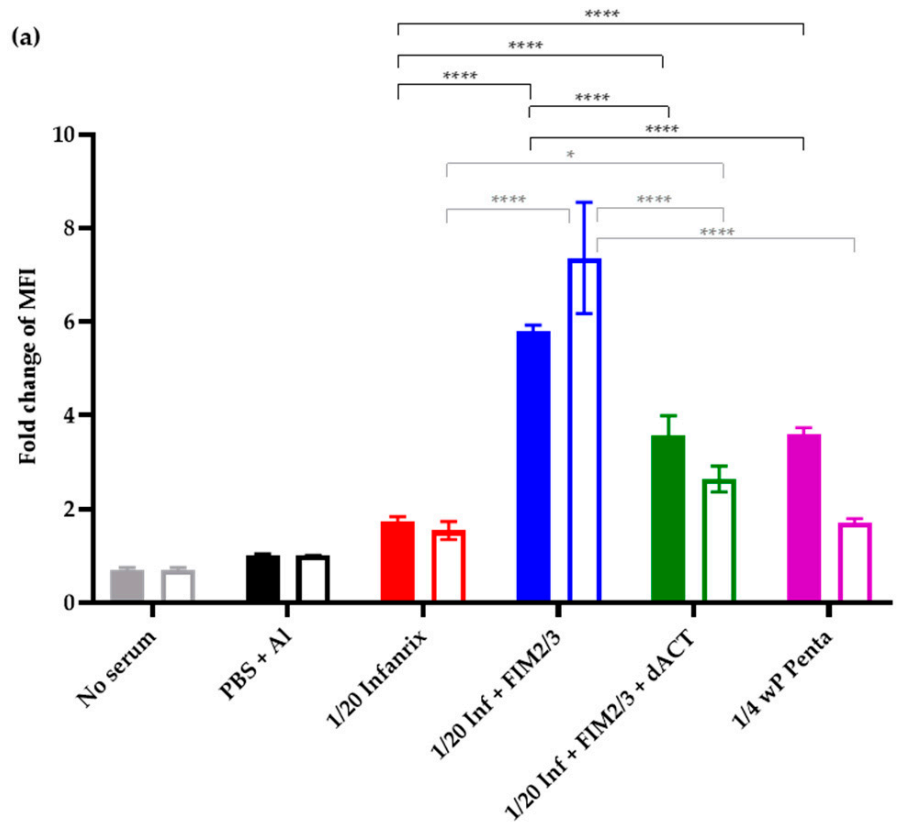

Figure 4. Cont. 
(b)

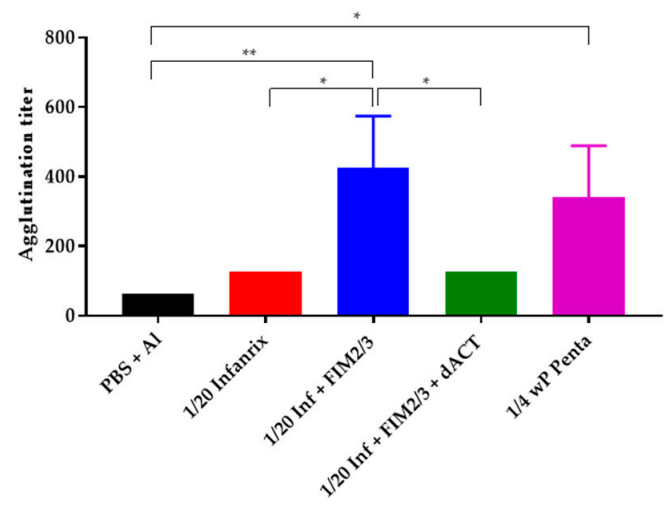

(d)

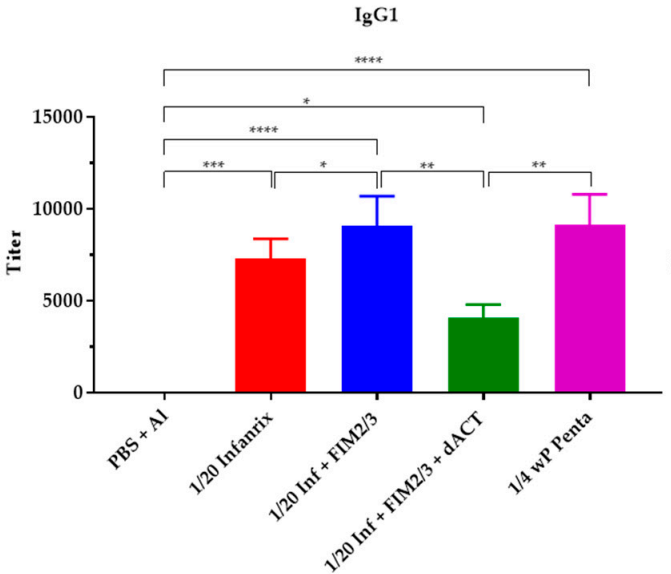

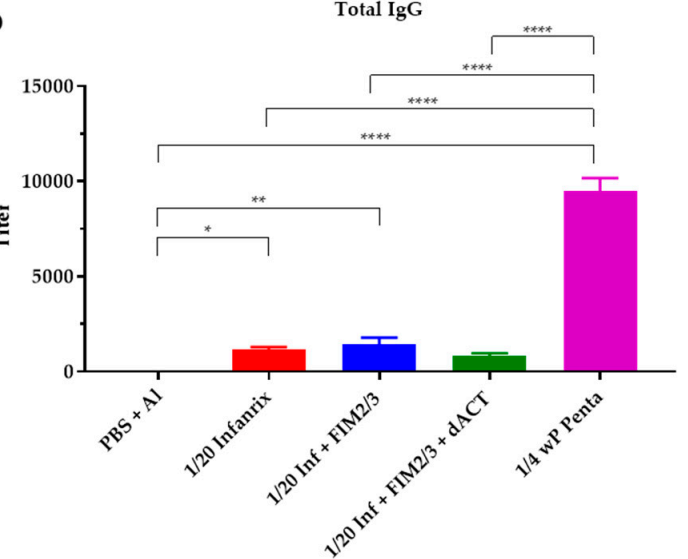

(e)

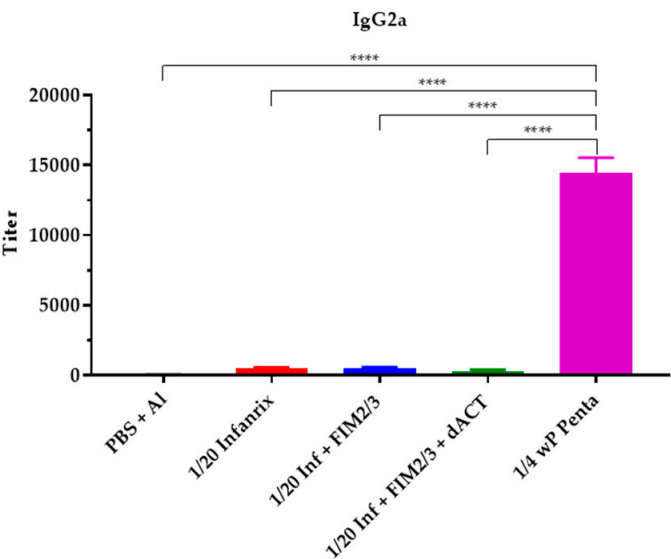

Figure 4. Innate and adaptive immune response elicited in BALB/c mice immunized by 1/20 HD of antigen-supplemented Infanrix ${ }^{\circledR}$ aP vaccine. (a) Sera from mice immunized as described in the legend of Figure 3 were obtained on day 35 and heat-treated for complement inactivation (empty bars) or not (full bars) before use for opsonization of mScarlet-expressing B. pertussis bacteria. Opsonophagocytic uptake into differentiated HL-60 cells was performed as described in the Materials and Methods and analyzed by flow cytometry. A representative experiment performed in triplicate is shown. The fold change of mean fluorescence intensity (MFI) was calculated by dividing the MFI obtained in the presence of immune plasma by the MFI obtained upon incubating cells with bacteria in the presence of plasma from PBS + alum vaccinated mice. Data are shown as mean \pm SD. Tukey's multiple comparison test was used to analyze the statistical significance between groups. Only significant differences are indicated. $*(p<0.05){ }^{* * * *}(p<0.0001)$. (b) Agglutination titers of the sera were determined as the last dilution that agglutinated the standardized B. pertussis cell reagent (TestLine Clinical Diagnostics). $n=3$ biological replicates performed in triplicates. Data shown as mean \pm SD. Tukey's multiple comparison test was used to analyze the statistical significance between groups. Only significant differences are indicated. * $(p<0.05) ;{ }^{* *}(p<0.01)$. (c-e) Antibody responses to B. pertussis elicited by the various vaccine combinations were determined by whole-cell ELISA on plates coated by heat-killed B. pertussis BPSM using anti-total mouse IgG or IgG1 or IgG2a-specific secondary antibodies. Results represent the mean antibody titers determined as the inflection points of the titration curves \pm SD. A pool of sera of six mice per group was used in triplicates, and two-way ANOVA followed by Tukey's multiple comparison test was performed to analyze the statistical significance between groups. ${ }^{*}(p<0.05) ;{ }^{* *}(p<0.01)$; $* * *(p<0.001) ; * * * * 0.0001)$. 

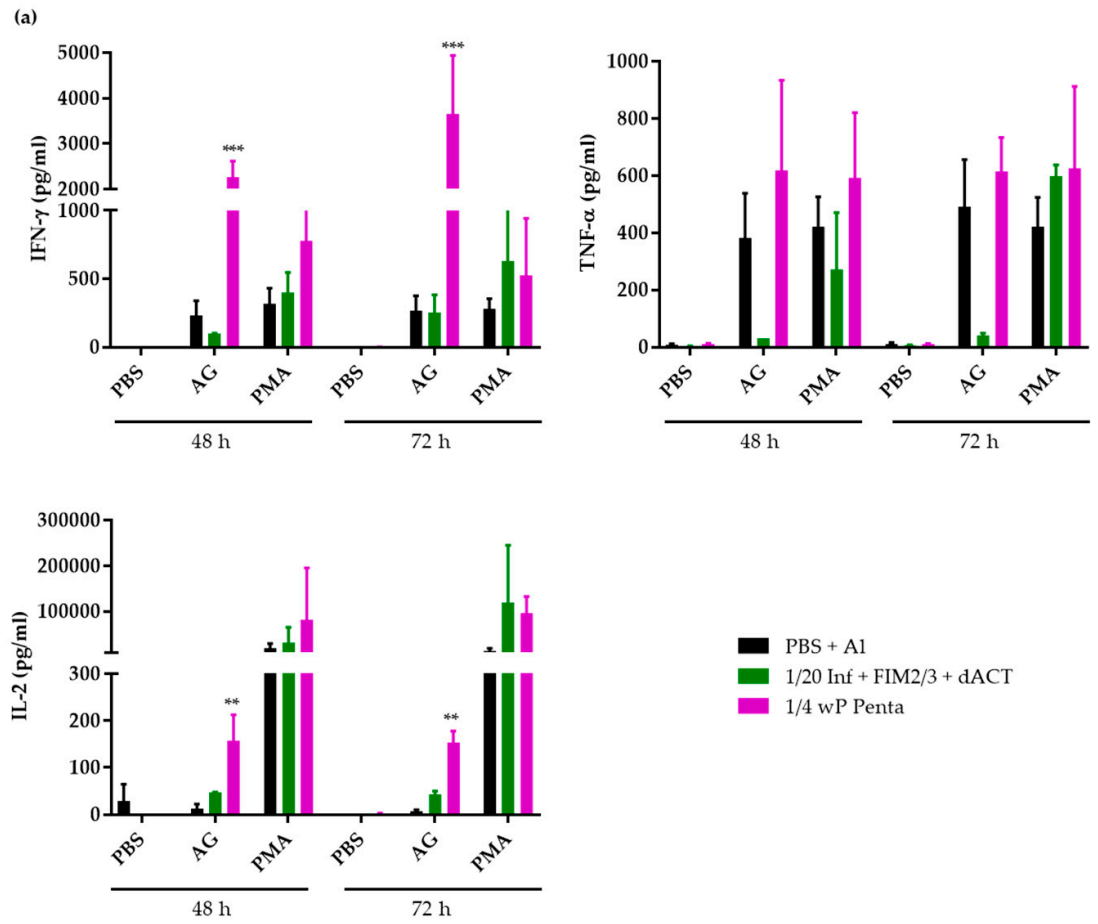

$$
\begin{aligned}
& \mathrm{PBS}+\mathrm{Al} \\
& 1 / 20 \mathrm{Inf}+\mathrm{FIM} 2 / 3+\mathrm{dACT} \\
& 1 / 4 \mathrm{wP} \text { Penta }
\end{aligned}
$$

(b)
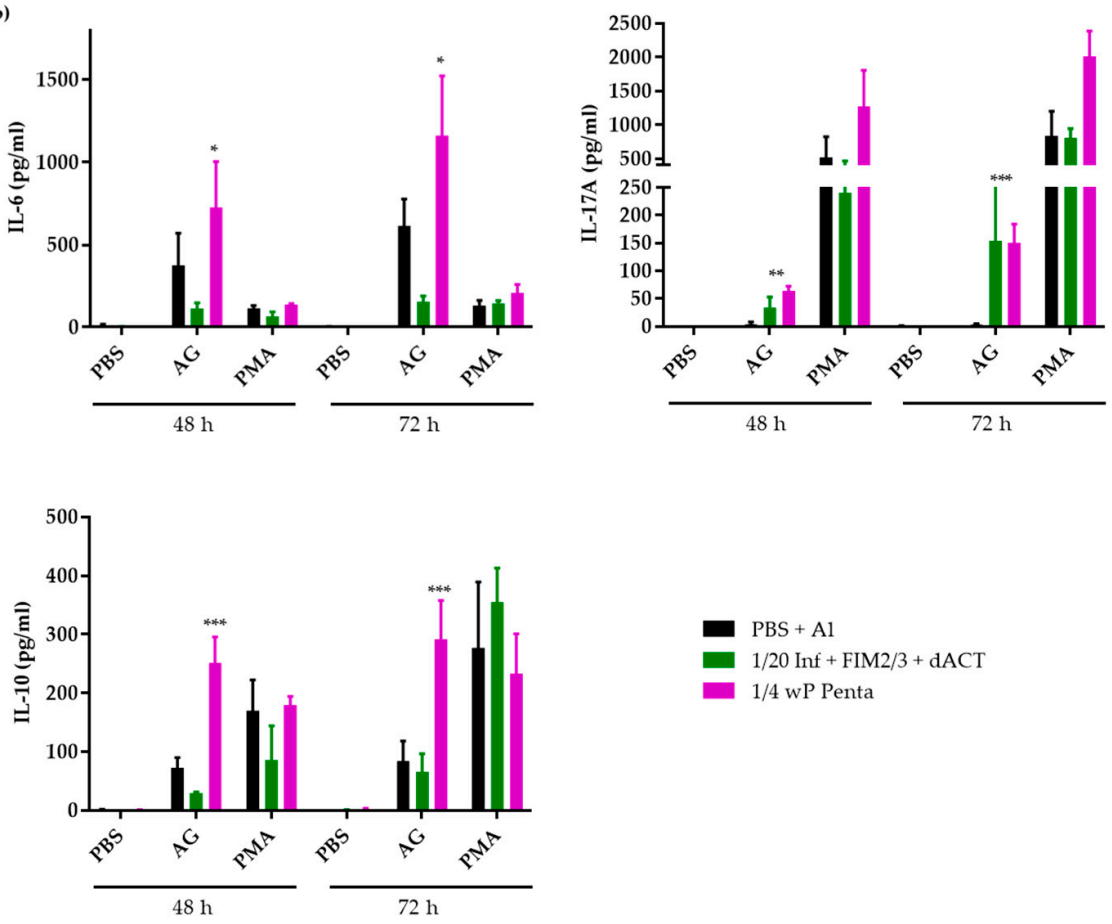

PBS + A

$1 / 20 \operatorname{Inf}+\mathrm{FIM} 2 / 3+\mathrm{dACT}$

$1 / 4$ wP Penta

Figure 5. Cytokine secretion by restimulated splenocytes of BALB/c mice immunized by 1/20 HD of antigen-supplemented Infanrix ${ }^{\circledR}$ aP vaccine. (a) Th1 cytokines. (b) IL-6, Il-17A and IL-10 cytokines. Splenocytes from four mice per time point were restimulated for 48 or $72 \mathrm{~h}$ using the antigen combinations used for immunizations ( $\mathrm{AG}=$ mixture of all antigens used for immunizations). Two supernatants per time point were pooled and cytokine concentrations were measured in duplicates using a cytokine bead assay, as described in detail in the Materials and Methods. Sham stimulation with PBS and unspecific polyclonal stimulation with phorbol myristate acetate (PMA) plus ionomycin were used as negative and positive control, respectively. Data shown as mean \pm SD. ${ }^{*}(p<0.05)$; $^{* *}(p<0.01){ }^{* * *}(p<0.001)$ vs. negative control mice. 


\section{Discussion}

We report that various parenterally applied acellular pertussis vaccine compositions triggered a sterilizing immunity in mouse lungs but compromised the natural capacity of BALB/C mice to clear the $B$. pertussis infection from the nasal cavity. Vaccination with $1 / 20 \mathrm{HD}$ of aP vaccine, whether supplemented with FIM2/3, LOS and dACT antigens or not, ablated the capacity of BALB/c mice to clear the infection from the nasal mucosa, despite enabling a rapid and full clearance of $B$. pertussis from infected lungs. The mechanism responsible for this troubling observation remains to be established, but the hypothesis of mispriming or compromising of mucosal immune defenses by the aP vaccine appears rather plausible.

Fractions of the human dose of aP vaccines were found to efficiently elicit immunity protecting mouse lungs from $B$. pertussis infection [21,23,28,36,37,49-52]. However, the comparison of published data is difficult. Various mouse strains, immunization routes, vaccine doses and compositions were used in various regimens, and varying infectious challenge doses of different $B$. pertussis strains were applied in varying suspension volumes, either directly into mouse nares, or as inhaled aerosol. Moreover, the two aP vaccines formulated into pediatric hexavaccines available in Europe differ in composition, with one (Hexacima ${ }^{\circledR}$, Sanofi) containing $25 \mu \mathrm{g}$ of detoxified PT (dPT) plus $25 \mu \mathrm{g}$ of filamentous hemagglutinin (FHA) and the other (Infanrix ${ }^{\circledR}$, GSK) also containing $8 \mu \mathrm{g}$ of PRN per dose.

In this study we used the BALB/c mouse lung infection clearance model, since the BALB/c mice are prone to development of Th2-polarized immune responses, like human infants are, and Th polarization has been shown to play a major role in immune protection against $B$. pertussis infections $[21,51,53]$. Indeed, Dubois and co-workers (C. Locht, personal communication) recently found that immunization by the aP vaccine blunted the expansion of $B$. pertussis antigen-specific IL-17 and IFN- $\gamma$-secreting CD103 ${ }^{+}$ $\mathrm{CD}_{4}{ }^{+} \mathrm{CD} 9^{+} \mathrm{CD}^{+}$tissue resident memory $\mathrm{T}$ cells $\left(\mathrm{T}_{\mathrm{RM}}\right)$ in the nasal mucosa of $B$. pertussis-infected BALB/c mice (Dubois et al., -submitted). Such $\mathrm{T}_{\mathrm{RM}}$ responses were found to be required for an initial protection of mouse airway mucosa from B. pertussis infection in the more Th1-prone C57Bl/6 mice and were only induced by natural infection, or by the $\mathrm{wP}$ vaccine, but not by the conventional alum-adjuvanted aP vaccines $[22,23,25,27,28]$. These data thus call for investigation of the mechanism by which by the alum-adjuvanted aP vaccine would blunt the establishment of the mucosa-homing $\mathrm{T}_{\mathrm{RM}}$ cells.

Intriguingly, in our experiments, despite a high efficacy in the lung clearance model and the induction of Th1/Th17-polarized immune responses, even immunization with 1/4 HD of the wP vaccine conferred only about a 10-fold reduction of the initial bacterial burden in the noses of immunized mice on day 7 (c.f. Figure 3b). Vaccination with the wP did not accelerate the clearance of nasal infection when compared with the natural capacity of sham-vaccinated BALB/c mice to eliminate B. pertussis from the nasal cavity. Both control and wP-immunized mice cleared the nasal infection with similar kinetics within 50 days after challenge. In contrast, Wilk and colleagues observed a substantial wP-induced protection of $\mathrm{C} 57 \mathrm{Bl} / 6$ mouse nasal mucosa from B. pertussis infection and colonization $[23,27,28]$. This discrepancy could be due to difference of immune polarization of responses in the C57Bl/6 versus $\mathrm{BALB} / \mathrm{c}$ mice and the different bacterial doses used for nose infection. In this study, we have directly applied over $10^{6} \mathrm{CFU}$ of $B$. pertussis bacteria into the nares of BALB/c mice. In contrast, Wilk and colleagues performed an aerosol infection challenge and recovered bacteria by nasal wash, possibly not recovering the bacteria growing in a biofilm on the nasal septum [54] and thus obtained less than $10^{3}$ CFUs from the nasal cavities of challenged animals. At the high initial infection dose used by us, with homogenization of noses prior to plating, only a modest initial reduction of the nasal CFU load occurred in the $\mathrm{wP}$-vaccinated animals, and a modest proliferation of bacteria was observed in the nasal cavity of sham-vaccinated animals over the first 7 days. The protective $C D 4^{+} \mathrm{T}_{\mathrm{RM}}$ response elicited by the $\mathrm{wP}$ vaccine $[23,27,28]$, if induced, would appear as insufficient for full containment of a high infectious dose in the likely absence of specific sIgA immunity. Indeed, the vaccines were administered parenterally and even the wP vaccine most likely did not trigger any $B$. pertussis-specific sIgA response. Hence, the $\mathrm{T}_{\mathrm{RM}}$-produced IL-17, which upregulates antimicrobial peptides and innate 
polyspecific sIgA in mucosal secretions and/or the IL-17-elicited attraction of neutrophils to the infected mucosa in wP-vaccinated animals, would only partially contain a high bacterial load. Nevertheless, we still believe that there is a real value to the use of the $\mathrm{wP}$ vaccine. In the natural situation of aerosol-transmitted infection, the $B$. pertussis dose received by a human is likely to be much lower than the dose used here for infection of mice that are quite resistant to B. pertussis colonization [55]. The spectacular control of pertussis incidence following the introduction of wP vaccine in the developed countries and the persisting control of pertussis in countries still using the $\mathrm{wP}$ vaccine clearly suggest that the $\mathrm{wP}$ vaccine not only prevents clinical pertussis, but also importantly reduces carriage and transmission of the pathogen.

Previous studies reported that addition of different protective antigens improved the efficacy of $\mathrm{aP}$ vaccines in the mouse lung infection clearance model and extended lung protection from $B$. pertussis infection. Queenan and coworkers reported improvement of a dPT plus FHA-comprising aP vaccine efficacy upon addition of FIM2/3 [52]. Addition of the adenylate cyclase toxoid or of the dACT-derived RTX antigen also improved the protective efficacy of a diluted aP vaccine in the mouse lung clearance model $[36,37]$. Indeed, we also show here that addition of FIM2/3 with B. pertussis LOS importantly improved the efficacy of the $1 / 20 \mathrm{HD}$ of commercial aP vaccine-elicited immune protection against mouse lungs infection by B. pertussis (c.f. Figure 3a). Curiously, this was not further enhanced by addition of high amounts of the LPS-free dACT antigen (30 $\mu$ g) that triggered ACT-neutralizing antibodies and hence was expected to enhance opsonophagocytic clearance of $B$. pertussis infection from mouse lungs. This is surprising, as E. coli LPS-contaminated dACT alone was previously found to be a potent protective antigen in the BALB/c mouse lung clearance model [33,34]. Moreover, an LPS-free $\mathrm{dACT}$ vaccine also conferred some protection from $B$. pertussis infection of mouse lungs [35]. It deserves to be explored why addition of LPS-free dACT resulted in somewhat reduced titers of antibodies against the other antigens (e.g., dPT, FHA and PRN, Figure S2) and thus blunted slightly the enhanced mouse lung protection from infection conferred by FIM2/3 and LOS addition into the diluted aP vaccine. It is possible that too high an amount of the immunodominant dACT antigen was used here.

Using an mScarlet-expressing fluorescent B. pertussis strain, we have developed an opsonophagocytic uptake assay for assessment of functional activity of antibodies induced by the aP vaccine and observed that in the absence of aP supplementation, the sera elicited by $1 / 20 \mathrm{HD}$ of the aP vaccine (Infanrix ${ }^{\circledR}$ ) performed poorly in the OPA assay. Serum from mice vaccinated with the 1/20 HD of aP vaccine supplemented with FIM2/3 and LOS mediated an enhanced opsonophagocytic uptake of $B$. pertussis by differentiated human HL-60 cells. Nevertheless, addition of FIM2/3 and LOS into the diluted aP vaccine did not confer any improved protection from nasal colonization by $B$. pertussis. Counterintuitively, addition of the dACT antigen into the diluted aP vaccine allowed the induction of ACT-neutralizing antibodies, but caused some inhibition of the capacity of the immune sera obtained to mediate opsonophagocytic uptake of B. pertussis bacteria. This was likely due to reduced titers of the opsonizing antibodies recognizing primarily the LOS, PRN and FIM2/3 antigens (c.f. Figure S3).

The cAMP-elevating action of ACT was previously shown to near-instantly ablate the bactericidal capacities of neutrophils, such as their oxidative burst and opsonophagocytic killing capacities $[39,56,57]$. ACT also compromises the capacity of neutrophils to phagocytose antibody-opsonized B. pertussis bacteria, and this inhibition can be alleviated by neutralization of ACT by antibodies of the immune sera $[58,59]$. Therefore, it is generally assumed that ACT-neutralizing antibodies might play an important role in fostering of bactericidal action of phagocytes in the initial stages of airway infection. However, the production of ACT-neutralizing serum IgG did not enhance the clearance of B. pertussis from the lungs and the nasal cavity in the experiments reported here. When dACT was added into the aP vaccine used, the neutralization of ACT activity appeared to have been negatively compensated by the reduction of titers of the opsonizing antibodies. Furthermore, induction of ACT-neutralizing secretory IgA on the airway mucosa may be needed for enhanced immune protection in the nose. Indeed, the major limitation of most of the reported mouse vaccination studies, including this one, is that the aP vaccines were applied parenterally and not mucosally. Hence, secretory IgA responses 
were not induced at the nasal mucosa. Humoral responses were, indeed, efficiently elicited upon nasal colonization by a live attenuated $B$. pertussis vaccine strain BPZE1 that triggered protection against subsequent nasal colonization by virulent $B$. pertussis [25].

Pertussis is a re-emerging infectious disease in many countries with high aP vaccine coverage. The licensed alum-adjuvanted aP vaccines efficiently prevent clinical pertussis disease in the first years after primovaccination. However, experimental evidence from a non-human primate model of infected olive baboons (Papio Anubis) would suggest that the aP vaccine does not prevent $B$. pertussis colonization of the respiratory tract and transmission to aP-vaccinated or unvaccinated animals [19]. Our data obtained in the mouse model are consistent with data from the baboon model and provide further evidence on the limitations of the current aP vaccines. The pertussis resurgence and outbreaks occurring in highly aP-vaccinated populations of many developed countries point to a high level of more-or-less asymptomatic and undiagnosed nasopharyngeal carriage and transmission of $B$. pertussis by aP-vaccinated individuals $[18,20]$. It will be important to determine what role in this phenomenon is played by the predominant Th2 polarization of aP-induced immune responses, absence of induction of mucosa-homing $\mathrm{T}_{\mathrm{RM}}$ cells and the narrow spectrum of antigens delivered by the aP vaccine, respectively, as compared to the Th1-polarizing and broad antigenic spectrum delivered by wP vaccines. A plausible component of the aP vaccine problem could also be an "original antigenic sin" elicited by the chemically detoxified PT (dPT) toxoid. dPT has tertiary structure collapsed due to the chemical treatment that destroys about $80 \%$ of the conformational epitopes targeted by the toxin-neutralizing antibodies [60]. Plausibly, then, aP-vaccinated individuals respond to production of native PT in the course of infectious challenge primarily with non-neutralizing antibodies recognizing neoepitopes and linear epitopes of dPT, that may eventually hamper the neutralization of native PT action by a mechanism of linked epitope suppression. Indeed, Auderset and co-workers recently showed that booster vaccination with an experimental aP vaccine containing the genetically detoxified PT with preserved neutralizing epitopes and a TLR9A adjuvant, yielded a superior Th1-associated IgG2a antibody response capable to boost the aP prime, which translated into improved protection against a $B$. pertussis challenge [61].

Accumulated clinical evidence from the large-scale use of aP vaccine in humans clearly shows that levels of native PT-neutralizing antibodies elicited by the aP vaccine in primovaccinated infants are sufficient for conferring a life-saving protection against systemic effects of PT action and for prevention of clinical pertussis disease symptoms, such as hyperleukocytosis. However, given the parenteral application of the vaccine, the PT-neutralizing IgG antibody levels elicited by the present aP vaccine may be insufficient for controlling the local suppression of innate and adaptive immune defense mechanisms of the upper airway mucosa by the native PT released by the B. pertussis closely adhering to the ciliated epithelial cells of the nasopharynx. Hence, insufficient neutralization of the locally produced PT in mucosal tissue may support the establishment of long-term bacterial colonization. This hypothesis can now be tested with a reformulated aP vaccine containing the genetically detoxified gdPT antigen with superior protective immunogenicity, which has a preserved tertiary structure with fully preserved conformational neutralizing epitopes [62-65].

\section{Conclusions}

Immunization of $\mathrm{BALB} / \mathrm{c}$ mice with a reduced dose of the aP vaccine ablated their natural capacity to eliminate $B$. pertussis infection from the nasal cavity and promoted persistent nasal colonization. In contrast, sham-vaccinated mice that received only the alum adjuvant in PBS were still able to clear the nasal infection as efficiently as the wP-vaccinated mice. This shows that it is not the adjuvant alone that compromises the innate capacity of mice to clear the nasal infection. Our results suggest that some component common to the two different formulations of the aP vaccines used (dPT or FHA, or both in synergy) prevents the mobilization of effective innate mucosal defense and inhibits the development of an adaptive mucosal immune response required for effective clearance of high-dose $B$. pertussis infection from the nose. It will be important to decipher the mechanism responsible, since extended nasopharyngeal colonization was previously observed also in aP-vaccinated and B. pertussis-challenged 
non-human primates [19], a model that mimics the natural infection of human upper airways by B. pertussis more faithfully than the mouse nasal clearance model used here. [62].

Supplementary Materials: The following are available online at http://www.mdpi.com/2076-393X/8/4/695/s1, Figure S1: Determination of the aP vaccine dose conferring a limited protection against intranasal B. pertussis challenge in BALB/C mice. Figure S2: Neutralization of toxin activities of ACT by sera of immunized mice. Figure S3: Total serum IgG antibody responses to the five vaccines antigens.

Author Contributions: Conceptualization, P.Š., J.H., O.S.; L.B. (Ludmila Brázdilová), A.R.G.; methodology, J.H., O.S., L.B. (Ludmila Brázdilová), J.M., F.A.; validation, J.H., O.S., L.B. (Ludmila Brázdilová); formal analysis P.Š., J.H.; investigation, J.H., O.S., J.M., L.B. (Ludmila Brázdilová), L.B. (Ladislav Bumba); resources, P.Š.; data curation, J.H., O.S., L.B. (Ludmila Brázdilová), J.M., L.B. (Ladislav Bumba); writing-original draft preparation, J.H., L.B. (Ludmila Brázdilová); writing—review and editing, P.Š., A.R.G.; visualization, J.H., L.B. (Ludmila Brázdilová), J.M.; supervision, J.H., O.S., L.B. (Ladislav Bumba), P.Š.; project administration, J.H., O.S., P.Š.; funding acquisition, P.Š. All authors have read and agreed to the published version of the manuscript.

Funding: This research was funded by the grant 19-27630X (P.Š.) from Czech Science Foundation and the EATRIS infrastructure LM2018133 (P.Š.) from the Ministry of Education, Youth and Sports of the Czech Republic, (P.Š.).

Acknowledgments: We thank Iva Maršíková for excellent technical help. Camille Locht, Violaine Dubois and Jonathan Chatagnon (French National Institute of Health and Medical Research (Inserm), Institut Pasteur de Lille, France) are gratefully acknowledged for the gift of the B. pertussis BPSM strain, for sharing of unpublished results and the stimulating discussions. The authors wish to thank Anne-Sophie Debrie and Loic Coutte (French National Institute of Health and Medical Research (Inserm), Institut Pasteur de Lille, France) for introduction of mouse nose dissection. Jitka Mucksova (BIOPHARM, Research Institute of Biopharmacy and Veterinary Drugs, Czech Republic) for introduction of splenocyte isolation and restimulation Cytokine assay data were collected at the Czech Centre for Phenogenomics supported by the Czech Academy of Sciences RVO 68378050 and by the project of support programme for large infrastructures for research, experimental development and innovation LM2018126 Czech Centre for Phenogenomics provided by Ministry of Education, Youth and Sports of the Czech Republic.

Conflicts of Interest: P.Š. is co-inventor of patent applications protecting the use of ACT toxoid in pertussis vaccines and is a founder and shareholder of Revabiotech SE, which is developing a new generation of the whole-cell pertussis vaccine. The funders had no role in the design of the study; in the collection, analyses, or interpretation of data; in the writing of the manuscript, or in the decision to publish the results.

\section{Abbreviations}

$\begin{array}{ll}\text { ACT } & \text { adenylate cyclase toxin } \\ \text { AG } & \text { antigens } \\ \text { aP } & \text { acellular pertussis } \\ \text { CFUs } & \text { colony forming units } \\ \text { dACT } & \text { adenylate cyclase toxoid } \\ \text { D-MEM } & \text { Dulbecco's Modified Eagle's Medium } \\ \text { dPT } & \text { detoxified pertussis toxin } \\ \text { DTwP } & \text { diphtheria-tetanus-whole-cell pertussis vaccine } \\ \text { EU } & \text { endotoxin unit } \\ \text { FHA } & \text { filamentous hemagglutinin } \\ \text { FIM } & \text { fimbriae } \\ \text { HD } & \text { human dose } \\ \text { LOS } & \text { outer membrane lipooligosaccharide } \\ \text { LPS } & \text { lipopolysaccharide } \\ \text { MOI } & \text { multiplicity of infection } \\ \text { OPA } & \text { opsonophagocytic uptake assay } \\ \text { PBS } & \text { phosphate-buffered saline } \\ \text { PMA } & \text { phorbol myristate acetate } \\ \text { PRN } & \text { pertactin } \\ \text { PT } & \text { pertussis toxin }\end{array}$


PRMI Roswell Park Memorial Institute medium

RTX repeats in toxin

TdaP tetanus-diphtheria-acellular pertussis vaccine

$\mathrm{T}_{\mathrm{RM}} \quad$ tissue resident memory $\mathrm{T}$ cells

${ }_{\mathrm{wP}} \quad$ whole-cell pertussis

\section{References}

1. Melvin, J.A.; Scheller, E.V.; Miller, J.F.; Cotter, P.A. Bordetella pertussis pathogenesis: Current and future challenges. Nat. Rev. Microbiol. 2014, 12, 274-288. [CrossRef]

2. Cherry, J.D. The 112-Year Odyssey of Pertussis and Pertussis Vaccines-Mistakes Made and Implications for the Future. J. Pediatr. Infect. Dis. Soc. 2019, 8, 334-341. [CrossRef] [PubMed]

3. Yeung, K.H.T.; Duclos, P.; Nelson, E.A.S.; Hutubessy, R.C.W. An update of the global burden of pertussis in children younger than 5 years: A modelling study. Lancet Infect. Dis. 2017, 17, 974-980. [CrossRef]

4. Klein, N.P.; Baine, Y.; Kolhe, D.; Baccarini, C.I.; Miller, J.M.; Van der Wielen, M. Five-year Antibody Persistence and Booster Response After 1 or 2 Doses of Meningococcal A, C, W and Y Tetanus Toxoid Conjugate Vaccine in Healthy Children. Pediatr. Infect. Dis. J. 2016, 35, 662-672. [CrossRef] [PubMed]

5. Koepke, R.; Eickhoff, J.C.; Ayele, R.A.; Petit, A.B.; Schauer, S.L.; Hopfensperger, D.J.; Conway, J.H.; Davis, J.P. Estimating the effectiveness of tetanus-diphtheria-acellular pertussis vaccine (Tdap) for preventing pertussis: Evidence of rapidly waning immunity and difference in effectiveness by Tdap brand. J. Infect. Dis. 2014, 210, 942-953. [CrossRef] [PubMed]

6. Shapiro, E.D. Acellular vaccines and resurgence of pertussis. JAMA 2012, 308, 2149-2150. [CrossRef] [PubMed]

7. Sheridan, S.L.; Ware, R.S.; Grimwood, K.; Lambert, S.B. Number and order of whole cell pertussis vaccines in infancy and disease protection. JAMA 2012, 308, 454-456. [CrossRef]

8. Tartof, S.Y.; Lewis, M.; Kenyon, C.; White, K.; Osborn, A.; Liko, J.; Zell, E.; Martin, S.; Messonnier, N.E.; Clark, T.A.; et al. Waning immunity to pertussis following 5 doses of DTaP. Pediatrics 2013, 131, e1047-e1052. [CrossRef]

9. Witt, M.A.; Arias, L.; Katz, P.H.; Truong, E.T.; Witt, D.J. Reduced risk of pertussis among persons ever vaccinated with whole cell pertussis vaccine compared to recipients of acellular pertussis vaccines in a large US cohort. Clin. Infect. Dis. 2013, 56, 1248-1254. [CrossRef]

10. Witt, M.A.; Katz, P.H.; Witt, D.J. Unexpectedly limited durability of immunity following acellular pertussis vaccination in preadolescents in a North American outbreak. Clin. Infect. Dis. 2012, 54, 1730-1735. [CrossRef]

11. Barkoff, A.M.; Mertsola, J.; Pierard, D.; Dalby, T.; Hoegh, S.V.; Guillot, S.; Stefanelli, P.; van Gent, M.; Berbers, G.; Vestrheim, D.; et al. Pertactin-deficient Bordetella pertussis isolates: Evidence of increased circulation in Europe, 1998 to 2015. Eurosurveillance 2019, 24, 1700832. [CrossRef]

12. Hellwig, S.M.; Rodriguez, M.E.; Berbers, G.A.; van de Winkel, J.G.; Mooi, F.R. Crucial role of antibodies to pertactin in Bordetella pertussis immunity. J. Infect. Dis. 2003, 188, 738-742. [CrossRef] [PubMed]

13. Martin, S.W.; Pawloski, L.; Williams, M.; Weening, K.; DeBolt, C.; Qin, X.; Reynolds, L.; Kenyon, C.; Giambrone, G.; Kudish, K.; et al. Pertactin-negative Bordetella pertussis strains: Evidence for a possible selective advantage. Clin. Infect. Dis. 2015, 60, 223-227. [CrossRef] [PubMed]

14. Pawloski, L.C.; Queenan, A.M.; Cassiday, P.K.; Lynch, A.S.; Harrison, M.J.; Shang, W.; Williams, M.M.; Bowden, K.E.; Burgos-Rivera, B.; Qin, X.; et al. Prevalence and molecular characterization of pertactin-deficient Bordetella pertussis in the United States. Clin. Vaccine Immunol. 2014, 21, 119-125. [CrossRef]

15. Williams, M.M.; Sen, K.; Weigand, M.R.; Skoff, T.H.; Cunningham, V.A.; Halse, T.A.; Tondella, M.L. CDC Pertussis Working Group. Bordetella pertussis Strain Lacking Pertactin and Pertussis Toxin. Emerg. Infect. Dis. 2016, 22, 319-322. [CrossRef]

16. Faulkner, A.E.; Skoff, T.H.; Tondella, M.L.; Cohn, A.; Clark, T.A.; Martin, S.W. Trends in Pertussis Diagnostic Testing in the United States, 1990 to 2012. Pediatr. Infect. Dis. J. 2016, 35, 39-44. [CrossRef]

17. Marchant, C.D.; Loughlin, A.M.; Lett, S.M.; Todd, C.W.; Wetterlow, L.H.; Bicchieri, R.; Higham, S.; Etkind, P.; Silva, E.; Siber, G.R. Pertussis in Massachusetts, 1981-1991: Incidence, serologic diagnosis, and vaccine effectiveness. J. Infect. Dis. 1994, 169, 1297-1305. [CrossRef] 
18. Althouse, B.M.; Scarpino, S.V. Asymptomatic transmission and the resurgence of Bordetella pertussis. BMC Med. 2015, 13, 146. [CrossRef]

19. Warfel, J.M.; Zimmerman, L.I.; Merkel, T.J. Acellular pertussis vaccines protect against disease but fail to prevent infection and transmission in a nonhuman primate model. Proc. Natl. Acad. Sci. USA 2014, 111, 787-792. [CrossRef]

20. Mills, K.H.; Ross, P.J.; Allen, A.C.; Wilk, M.M. Do we need a new vaccine to control the re-emergence of pertussis? Trends Microbiol. 2014, 22, 49-52. [CrossRef]

21. Redhead, K.; Watkins, J.; Barnard, A.; Mills, K.H. Effective immunization against Bordetella pertussis respiratory infection in mice is dependent on induction of cell-mediated immunity. Infect. Immun. 1993, 61, 3190-3198. [CrossRef]

22. Allen, A.C.; Wilk, M.M.; Misiak, A.; Borkner, L.; Murphy, D.; Mills, K.H.G. Sustained protective immunity against Bordetella pertussis nasal colonization by intranasal immunization with a vaccine-adjuvant combination that induces IL-17-secreting TRM cells. Mucosal Immunol. 2018, 11, 1763-1776. [CrossRef]

23. Misiak, A.; Wilk, M.M.; Raverdeau, M.; Mills, K.H. IL-17-Producing Innate and Pathogen-Specific Tissue Resident Memory gammadelta T Cells Expand in the Lungs of Bordetella pertussis-Infected Mice. J. Immunol. 2017, 198, 363-374. [CrossRef] [PubMed]

24. Ross, P.J.; Sutton, C.E.; Higgins, S.; Allen, A.C.; Walsh, K.; Misiak, A.; Lavelle, E.C.; McLoughlin, R.M.; Mills, K.H. Relative contribution of Th1 and Th17 cells in adaptive immunity to Bordetella pertussis: Towards the rational design of an improved acellular pertussis vaccine. PLoS Pathog. 2013, 9, e1003264. [CrossRef]

25. Solans, L.; Debrie, A.S.; Borkner, L.; Aguilo, N.; Thiriard, A.; Coutte, L.; Uranga, S.; Trottein, F.; Martin, C.; Mills, K.H.G.; et al. IL-17-dependent SIgA-mediated protection against nasal Bordetella pertussis infection by live attenuated BPZE1 vaccine. Mucosal Immunol. 2018, 11, 1753-1762. [CrossRef] [PubMed]

26. Warfel, J.M.; Edwards, K.M. Pertussis vaccines and the challenge of inducing durable immunity. Curr. Opin. Immunol. 2015, 35, 48-54. [CrossRef]

27. Wilk, M.M.; Borkner, L.; Misiak, A.; Curham, L.; Allen, A.C.; Mills, K.H.G. Immunization with whole cell but not acellular pertussis vaccines primes CD4 TRM cells that sustain protective immunity against nasal colonization with Bordetella pertussis. Emerg. Microbes Infect. 2019, 8, 169-185. [CrossRef] [PubMed]

28. Wilk, M.M.; Misiak, A.; McManus, R.M.; Allen, A.C.; Lynch, M.A.; Mills, K.H.G. Lung CD4 Tissue-Resident Memory T Cells Mediate Adaptive Immunity Induced by Previous Infection of Mice with Bordetella pertussis. J. Immunol. 2017, 199, 233-243. [CrossRef] [PubMed]

29. Bancroft, T.; Dillon, M.B.; da Silva Antunes, R.; Paul, S.; Peters, B.; Crotty, S.; Lindestam Arlehamn, C.S.; Sette, A. Th1 versus Th2 T cell polarization by whole-cell and acellular childhood pertussis vaccines persists upon re-immunization in adolescence and adulthood. Cell. Immunol. 2016, 304-305, 35-43. [CrossRef]

30. da Silva Antunes, R.; Babor, M.; Carpenter, C.; Khalil, N.; Cortese, M.; Mentzer, A.J.; Seumois, G.; Petro, C.D.; Purcell, L.A.; Vijayanand, P.; et al. Th1/Th17 polarization persists following whole-cell pertussis vaccination despite repeated acellular boosters. J. Clin. Investig. 2018, 128, 3853-3865. [CrossRef]

31. BMJ. VACCINATION against whooping-cough; relation between protection in children and results of laboratory tests; a report to the Whooping-cough Immunization Committee of the Medical Research Council and to the medical officers of health for Cardiff, Leeds, Leyton, Manchester, Middlesex, Oxford, Poole, Tottenham, Walthamstow, and Wembley. BMJ 1956, 2, 454-462.

32. Paddock, C.D.; Sanden, G.N.; Cherry, J.D.; Gal, A.A.; Langston, C.; Tatti, K.M.; Wu, K.H.; Goldsmith, C.S.; Greer, P.W.; Montague, J.L.; et al. Pathology and pathogenesis of fatal Bordetella pertussis infection in infants. Clin. Infect. Dis. 2008, 47, 328-338. [CrossRef]

33. Betsou, F.; Sebo, P.; Guiso, N. CyaC-mediated activation is important not only for toxic but also for protective activities of Bordetella pertussis adenylate cyclase-hemolysin. Infect. Immun. 1993, 61, 3583-3589. [CrossRef]

34. Betsou, F.; Sebo, P.; Guiso, N. The C-terminal domain is essential for protective activity of the Bordetella pertussis adenylate cyclase-hemolysin. Infect. Immun. 1995, 63, 3309-3315. [CrossRef]

35. Villarino Romero, R.; Bibova, I.; Cerny, O.; Vecerek, B.; Wald, T.; Benada, O.; Zavadilova, J.; Osicka, R.; Sebo, P. The Bordetella pertussis type III secretion system tip complex protein Bsp22 is not a protective antigen and fails to elicit serum antibody responses during infection of humans and mice. Infect. Immun. 2013, 81, 2761-2767. [CrossRef] 
36. Cheung, G.Y.; Xing, D.; Prior, S.; Corbel, M.J.; Parton, R.; Coote, J.G. Effect of different forms of adenylate cyclase toxin of Bordetella pertussis on protection afforded by an acellular pertussis vaccine in a murine model. Infect. Immun. 2006, 74, 6797-6805. [CrossRef]

37. Boehm, D.T.; Hall, J.M.; Wong, T.Y.; DiVenere, A.M.; Sen-Kilic, E.; Bevere, J.R.; Bradford, S.D.; Blackwood, C.B.; Elkins, C.M.; DeRoos, K.A.; et al. Evaluation of Adenylate Cyclase Toxoid Antigen in Acellular Pertussis Vaccines by Using a Bordetella pertussis Challenge Model in Mice. Infect. Immun. 2018, 86. [CrossRef]

38. Ahmad, J.N.; Holubova, J.; Benada, O.; Kofronova, O.; Stehlik, L.; Vasakova, M.; Sebo, P. Bordetella Adenylate Cyclase Toxin Inhibits Monocyte-to-Macrophage Transition and Dedifferentiates Human Alveolar Macrophages into Monocyte-like Cells. mBio 2019, 10, e01743-19. [CrossRef]

39. Cerny, O.; Anderson, K.E.; Stephens, L.R.; Hawkins, P.T.; Sebo, P. cAMP Signaling of Adenylate Cyclase Toxin Blocks the Oxidative Burst of Neutrophils through Epac-Mediated Inhibition of Phospholipase C Activity. J. Immunol. 2017, 198, 1285-1296. [CrossRef]

40. Sebo, P.; Osicka, R.; Masin, J. Adenylate cyclase toxin-hemolysin relevance for pertussis vaccines. Expert Rev. Vaccines 2014, 13, 1215-1227. [CrossRef]

41. Stainer, D.W.; Scholte, M.J. A simple chemically defined medium for the production of phase I Bordetella pertussis. J. Gen. Microbiol. 1970, 63, 211-220. [CrossRef]

42. Bindels, D.S.; Haarbosch, L.; van Weeren, L.; Postma, M.; Wiese, K.E.; Mastop, M.; Aumonier, S.; Gotthard, G.; Royant, A.; Hink, M.A.; et al. mScarlet: A bright monomeric red fluorescent protein for cellular imaging. Nat. Methods 2017, 14, 53-56. [CrossRef]

43. Kovach, M.E.; Phillips, R.W.; Elzer, P.H.; Roop, R.M., 2nd; Peterson, K.M. pBBR1MCS: A broad-host-range cloning vector. Biotechniques 1994, 16, 800-802.

44. Alexander, F.; Matheson, M.; Fry, N.K.; Labram, B.; Gorringe, A.R. Antibody responses to individual Bordetella pertussis fimbrial antigen Fim2 or Fim3 following immunization with the five-component acellular pertussis vaccine or to pertussis disease. Clin. Vaccine Immunol. 2012, 19, 1776-1783. [CrossRef]

45. Stanek, O.; Masin, J.; Osicka, R.; Jurnecka, D.; Osickova, A.; Sebo, P. Rapid Purification of Endotoxin-Free RTX Toxins. Toxins 2019, 11, 336. [CrossRef]

46. Villarino Romero, R.; Hasan, S.; Fae, K.; Holubova, J.; Geurtsen, J.; Schwarzer, M.; Wiertsema, S.; Osicka, R.; Poolman, J.; Sebo, P. Bordetella pertussis filamentous hemagglutinin itself does not trigger anti-inflammatory interleukin-10 production by human dendritic cells. Int. J. Med. Microbiol. 2016, 306, 38-47. [CrossRef]

47. van der Ark, A.; van Straaten-van de Kappelle, I.; Akkermans, A.; Hendriksen, C.; van de Donk, H. Development of pertussis serological potency test. Serological assessment of antibody response induced by whole cell vaccine as an alternative to mouse protection in an intracerebral challenge model. Biologicals 1994, 22, 233-242. [CrossRef]

48. Fabbrini, M.; Sammicheli, C.; Margarit, I.; Maione, D.; Grandi, G.; Giuliani, M.M.; Mori, E.; Nuti, S. A new flow-cytometry-based opsonophagocytosis assay for the rapid measurement of functional antibody levels against Group B Streptococcus. J. Immunol. Methods 2012, 378, 11-19. [CrossRef]

49. Godfroid, F.; Denoel, P.; de Grave, D.; Schuerman, L.; Poolman, J. Diphtheria-tetanus-pertussis (DTP) combination vaccines and evaluation of pertussis immune responses. Int. J. Med. Microbiol. 2004, 294, 269-276. [CrossRef]

50. Guiso, N.; Capiau, C.; Carletti, G.; Poolman, J.; Hauser, P. Intranasal murine model of Bordetella pertussis infection. I. Prediction of protection in human infants by acellular vaccines. Vaccine 1999, 17, 2366-2376. [CrossRef]

51. Mills, K.H.; Barnard, A.; Watkins, J.; Redhead, K. Cell-mediated immunity to Bordetella pertussis: Role of Th1 cells in bacterial clearance in a murine respiratory infection model. Infect. Immun. 1993, 61, 399-410. [CrossRef] [PubMed]

52. Queenan, A.M.; Dowling, D.J.; Cheng, W.K.; Fae, K.; Fernandez, J.; Flynn, P.J.; Joshi, S.; Brightman, S.E.; Ramirez, J.; Serroyen, J.; et al. Increasing FIM2/3 antigen-content improves efficacy of Bordetella pertussis vaccines in mice in vivo without altering vaccine-induced human reactogenicity biomarkers in vitro. Vaccine 2019, 37, 80-89. [CrossRef]

53. Zaghouani, H.; Hoeman, C.M.; Adkins, B. Neonatal immunity: Faulty T-helpers and the shortcomings of dendritic cells. Trends Immunol. 2009, 30, 585-591. [CrossRef] [PubMed] 
54. Conover, M.S.; Sloan, G.P.; Love, C.F.; Sukumar, N.; Deora, R. The Bps polysaccharide of Bordetella pertussis promotes colonization and biofilm formation in the nose by functioning as an adhesin. Mol. Microbiol. 2010, 77, 1439-1455. [CrossRef]

55. Weyrich, L.S.; Feaga, H.A.; Park, J.; Muse, S.J.; Safi, C.Y.; Rolin, O.Y.; Young, S.E.; Harvill, E.T. Resident microbiota affect Bordetella pertussis infectious dose and host specificity. J. Infect. Dis. 2014, 209, 913-921. [CrossRef]

56. Confer, D.L.; Eaton, J.W. Phagocyte impotence caused by an invasive bacterial adenylate cyclase. Science 1982, 217, 948-950. [CrossRef]

57. Kamanova, J.; Kofronova, O.; Masin, J.; Genth, H.; Vojtova, J.; Linhartova, I.; Benada, O.; Just, I.; Sebo, P. Adenylate cyclase toxin subverts phagocyte function by RhoA inhibition and unproductive ruffling. J. Immunol. 2008, 181, 5587-5597. [CrossRef] [PubMed]

58. Mobberley-Schuman, P.S.; Connelly, B.; Weiss, A.A. Phagocytosis of Bordetella pertussis incubated with convalescent serum. J. Infect. Dis. 2003, 187, 1646-1653. [CrossRef]

59. Weingart, C.L.; Mobberley-Schuman, P.S.; Hewlett, E.L.; Gray, M.C.; Weiss, A.A. Neutralizing antibodies to adenylate cyclase toxin promote phagocytosis of Bordetella pertussis by human neutrophils. Infect. Immun. 2000, 68, 7152-7155. [CrossRef]

60. Ibsen, P.H. The effect of formaldehyde, hydrogen peroxide and genetic detoxification of pertussis toxin on epitope recognition by murine monoclonal antibodies. Vaccine 1996, 14, 359-368. [CrossRef]

61. Auderset, F.; Ballester, M.; Mastelic-Gavillet, B.; Fontannaz, P.; Chabaud-Riou, M.; Reveneau, N.; Garinot, M.; Mistretta, N.; Liu, Y.; Lambert, P.H.; et al. Reactivating Immunity Primed by Acellular Pertussis Vaccines in the Absence of Circulating Antibodies: Enhanced Bacterial Control by TLR9 Rather Than TLR4 Agonist-Including Formulation. Front. Immunol. 2019, 10, 1520. [CrossRef] [PubMed]

62. Ausar, S.F.; Zhu, S.; Duprez, J.; Cohen, M.; Bertrand, T.; Steier, V.; Wilson, D.J.; Li, S.; Sheung, A.; Brookes, R.H.; et al. Genetically detoxified pertussis toxin displays near identical structure to its wild-type and exhibits robust immunogenicity. Commun. Biol. 2020, 3, 427. [CrossRef]

63. Blanchard Rohner, G.; Chatzis, O.; Chinwangso, P.; Rohr, M.; Grillet, S.; Salomon, C.; Lemaitre, B.; Boonrak, P.; Lawpoolsri, S.; Clutterbuck, E.; et al. Boosting Teenagers With Acellular Pertussis Vaccines Containing Recombinant or Chemically Inactivated Pertussis Toxin: A Randomized Clinical Trial. Clin. Infect. Dis. 2019, 68, 1213-1222. [CrossRef]

64. Pitisuttithum, P.; Chokephaibulkit, K.; Sirivichayakul, C.; Sricharoenchai, S.; Dhitavat, J.; Pitisuthitham, A.; Phongsamart, W.; Boonnak, K.; Lapphra, K.; Sabmee, Y.; et al. Antibody persistence after vaccination of adolescents with monovalent and combined acellular pertussis vaccines containing genetically inactivated pertussis toxin: A phase 2/3 randomised, controlled, non-inferiority trial. Lancet Infect. Dis. 2018, 18, 1260-1268. [CrossRef]

65. Sricharoenchai, S.; Sirivichayakul, C.; Chokephaibulkit, K.; Pitisuttithum, P.; Dhitavat, J.; Pitisuthitham, A.; Phongsamart, W.; Boonnak, K.; Lapphra, K.; Sabmee, Y.; et al. A genetically inactivated two-component acellular pertussis vaccine, alone or combined with tetanus and reduced-dose diphtheria vaccines, in adolescents: A phase 2/3, randomised controlled non-inferiority trial. Lancet Infect. Dis. 2018, 18, 58-67. [CrossRef]

Publisher's Note: MDPI stays neutral with regard to jurisdictional claims in published maps and institutional affiliations.

(C) 2020 by the authors. Licensee MDPI, Basel, Switzerland. This article is an open access article distributed under the terms and conditions of the Creative Commons Attribution (CC BY) license (http://creativecommons.org/licenses/by/4.0/). 